\title{
O nekim fonološkim i leksičkim osobitostima hrvatskoglagoljskoga Zbornika fra Šimuna Klimantovića iz 1512. godine
}

\begin{abstract}
Šimunu Klimantoviću, franjevcu trećorecu, pisaru sa statusom književnika, sa sigurnošću se mogu pripisati četiri rukopisa. Najopsežniji je među njima Klimantovićev zbornik I iz 1512. godine (RitKlim), većim dijelom ritual s različitim obredima, koji se čuva u Arhivu Provincijalata franjevaca trećoredaca u samostanu sv. Franje Ksaverskoga u Zagrebu. U radu se analiziraju neke osobitosti RitKlim-a na fonološkoj i leksičkoj razini, razinama najsnažnije podložnima utjecaju govornoga čakavskoga idioma. U fonološkoj analizi naglasak je stavljen na načine bilježenja znakova za jerove, na pitanje jata, refleks glasa $e$, slogotvorne $r$ i $l$, pisanje derva, slova $f$, čuvanje skupine $\check{c} r$ te alternacije $v / b$ u posuđenim riječima. Opisano je i nekoliko drugih fonoloških pojava koje su odraz govornoga jezika. U prikazu leksičkih osobitosti RitKlim-a naglasak je na posuđenicama iz kasnijega razdoblja kod kojih je vidljiv utjecaj govornoga jezika, pri čemu su izdvojene rijetke riječi nepotvrđene u Slovníku i u Rječniku crkvenoslavenskoga jezika Hrvatske redakcije. Izdvojeni su posebno i neki kroatizmi (čakavizmi i kajkavizmi), pri čemu su kod kajkavizama razlučeni oni koji pripadaju zajedničkom čakavsko-kajkavskom sloju, oni koji su dio kajkavskoga sloja te oni za koje nije sasvim sigurno pripadaju li kajkavskom ili čakavskom leksičkom sloju.
\end{abstract}

\section{Uvodna opaska}

Hrvatsko srednjovjekovlje s hrvatskoglagoljskom pisanom ostavštinom predstavlja nepresušan izvor proučavanja jezičnih pojava na našem prostoru u dijakronijskom i sinkronijskom smislu. Cjelokupna dosadašnja istraživanja u tom smislu dragocjeni su materijal bez kojega u potpunosti ne bismo mogli razumjeti ni suvremeni hrvatski jezik.

Još od 11. stoljeća, unatoč latinskomu kao jedinomu jeziku kulture i duhovnosti na kršćanskom Zapadu, ${ }^{1}$ aktualno je pitanje uvođenja narodnoga jezika u liturgiju

\footnotetext{
Vidi CURTIUS 1998.
} 
i prevođenja svetopisamskih tekstova. Na našim pak prostorima već od 12. i 13. stoljeća utjecaj narodnoga jezika na liturgijske tekstove i prijevodnu literaturu sve je veći. To je vidljivo u svim prijepisima nastalima u tome razdoblju, dok u 14 . stoljeću taj jezik prevladava u „nabožnoj i privatno-pravnoj, svjetovnoj literaturi““. Naša „najstarija hrvatska pjesmarica“, s duhovnim pjesmama, nastala vjerojatno 1380. godine, napisana je „gotovo sasvim u živom jeziku narodnome“. ${ }^{2}$ Dakle, neka od najstarijih djela hrvatske pismenosti napisana su na čakavštini. Uglavnom su to bili imovinski, privatni ili javni pravni spisi, zbornici, statuti, rukopisi religioznoga karaktera, matične knjige (libri), matrikule bratovština i sl. Utjecaj narodnoga govora na sastav hrvatskoglagoljskih zbornika mješovitoga sadržaja nije bio slučajan, niti posljedica jezične neukosti njihovih pisara. „Potvrdu tvrdnji da su glagoljaši dobro poznavali i normu crkvenoslavenskoga i latinskoga jezika, što nikako nije značilo zanemarivanje materinskoga idioma, nalazimo u dosljednoj primjeni različitih sustava s obzirom na njihovu tematiku. Osobni stav svakoga pisara ostavljen je u rubrikama, kronikama, kolofonima jer je jedino tu bilo moguće izići iz zadanih normi i tekstu dati autorski pečat. Tako je i u ovome Zborniku fra Šimuna Klimantovića“. ${ }^{3}$

\section{Franjevci trećoreci}

Višestoljetno postojanje franjevaca trećoredaca u Hrvatskoj seže u prvu polovinu 13. stoljeća. Prvi je siguran podatak o njima 22. studenoga 1235. zabilježen u Zadru. Već od samih početaka koriste se „u službi Božjoj glagoljicom i staroslavenskim jezikom i otad do najnovijih dana nose časni naslov glagoljaši “', koji je prvi put upotrijebljen 1483. godine uopće upravo za franjevce trećoredce iz prvićkoga samostana u Šibenskoj biskupiji. ${ }^{4}$ Produkcija franjevaca trećoredaca u hrvatskoglagoljskim srednjovjekovnim knjigama bogata je i značajna. Jedan je od mnogih vrijednih trećoredaca tvoraca glagoljskih knjiga i fra Šimun Klimantović.

\section{Fra Šimun Klimantović}

Šimun Klimantović poznat je znanosti kao jedna od triju najznačajnijih osoba tzv. glagoljskoga humanizma ili glagoljske humanističke književnosti. „Prvi je pisac poznat kao pisac triju obrednika" , ${ }^{5}$ koji je pažljivo odabrao, posložio, spojio, ali i samostalno napisao tekstove što mu je, bez daljnjega, osiguralo epitet

2 Vidi ZELIĆ-BUČAN 1972; MALIĆ 1972; DAMJANOVIĆ 2000: 21-22.

3 Vidi HERCIGONJA 2004: 74-75.

4 RUNJE 2012, 15-16.

5 Vidi RUNJE 2015: 80. 
književnoga stvaraoca. Osim toga, svojim je duhovitim osobnim komentarima, koji čitatelju izmame osmijeh, puno rekao i o vlastitoj osobnosti.

U zadarskim javnobilježničkim spisima nalazi se nekoliko zabilješki u kojima saznajemo o fra Šimunovu životu. ${ }^{6}$ Prvi je podatak o njemu iz dokumenta od 13. kolovoza 1486. godine prema kojem „Mariza uxor Bartholi Hranoevich de Lucorano, Johannes filius Georgii Clemenich de dicta Insula, Elena uxor Antonii Livacich de Jadra, Matheus et Gregorius fratres filii dicti Georgii Clemenich" daju neki posjed ,fratri Simeoni Clemenich". ' Zbog tzv. Klimantovićevih konstitucija značajan je podatak da je fra Šimun bio prisutan na redodržavnom zboru, odnosno na kapitulu održanu na otočiću Galevcu (Školjiću) kod Prika na otoku Ugljanu, gdje su se 12. travnja 1492. godine utanačile „redovske naredbe“, koje je upravo on sastavio i zapisao kao kustacione. Tom je prilikom na kapitulu bio imenovan gvardijanom školjićkoga samostana, ${ }^{8}$ a nekoliko je godina kasnije postao ,provincijski ministar zajednice franjevaca trećoredaca glagoljaša u Dalmaciji““.9 Fra Šimun je dugo službovao kao provincijal. Uvriježeno je mišljenje da je umro oko 1544. godine u samostanu na Glavotoku. ${ }^{10}$ Međutim, prema arhivskim podacima, najkasniji je spomen o fra Šimunu Klimantoviću iz 1518. godine, ${ }^{11}$ a tek je mogućnost da je zajedno s još šestoricom braće 1527. godine živio u Zadru, gdje su se neki njegovi fratri sklonili pred osmanskom opasnosti. ${ }^{12}$

Iako mu se pripisivalo pet, sa sigurnošću se može govoriti o četirima rukopisima koje je fra Šimun napisao. Od toga su tri zbornika: Klimantovićev zbornik I dovršen 1512. godine, koji je oduvijek u posjedu trećoredaca i čuva se u Arhivu Provincijalata franjevaca trećoredaca u samostanu sv. Franje Ksaverskoga u Zagrebu, Klimantovićev zbornik II iz 1514. godine, koji se danas čuva u Ruskoj nacionalnoj knjižnici u Petrogradu (br. 1 Berčićeve zbirke), Klimantovićev zbornik III iz 1509. godine, koji se danas čuva u Ruskoj nacionalnoj knjižnici u Petrogradu (br. 2 Berčićeve zbirke), a četvrti je zbirka povelja i oprosta Mare Magnum, koja se čuva u Nacionalnoj i sveučilišnoj knjižnici u Zagrebu pod signaturom $R 3368$.

\footnotetext{
Više o njegovu životu vidi RUNJE 2015.

7 PAZ SZN, Gregorio de Bosco, B. III, sv. 3, fol. 4, 13. VIII. 1486. - iz rukopisnih bilježaka fra Petra Runje. Vidi i RUNJE 2015: 29.

8 Vidi RUNJE 1998: 74; Isti 2012: 195; Isti 2015: 31-32.

9 Vidi Isti 2015: 32.

10 Vidi SRDOČ-KONESTRA I LAJŠIĆ 2008: 79.

11 Vidi RUNJE 2015: 78.

12 Vidi Isti 2012: 194; Isti 2015: 90-91.
} 


\section{RitKlim}

Zbornik fra Šimuna Klimantovića I (RitKlim) njegov je sastavljač, a dijelom i autor, kako navode fra Stjepan Ivančić i Ivan B(e)rčić, počeo pisati u crkvi sv. Frane na Komrčaru na Rabu, ${ }^{13}$ a dovršio u Zaglavu, u franjevačkom samostanu, 23. veljače 1512. godine. ${ }^{14}$ Tako je i sam fra Šimun zabilježio na posljednjoj stranici rukopisa. To je njegov prvi i najopsežniji zbornik napisan prvenstveno za franjevce trećorece, ali i popove glagoljaše, kako bi se puku približili crkveni obredi i običaji kroz katoličku godinu. Ispisan je na pergameni i sastoji se od 235 listova, odnosno 470 stranica. Prema njegovu sastavu, tj. funkciji, raznolik je i sadrži:

- sakramente kao što su S'povidb, Naukb spovidi p(o)pu, Naukb č(lovi)ku na $s p(o) v(i) d i$, Naukb spov(i)dniku

- sakramentale kao što su Priporučenie d(u)̌̌e, Pogrêbb mr(')tvihb, Pogrêbb dič'čice

- različite blagoslove kao što su Bl(agoslo)vb voĉa i kruha, ên'ca na vazam', jinihb mesb ili p’tcb, sira i jâjb, kuĉe nove ili mes'ta nova, vsake pice, nove p'lavi, varine

- obrede namijenjene franjevačkomu redu kao što su Rêgula pokor'nihb, Tas 'tamen 'tb, Oficii obučeniê, Profess pokor'nihb, Kus 'tacioni pokor(')n(i)h'

- obrede namijenjene općoj upotrebi kao što su glave. $\widetilde{\ddot{i}} \cdot[10]$ zap $(o) v(i)$ di b(o)

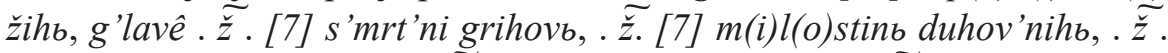

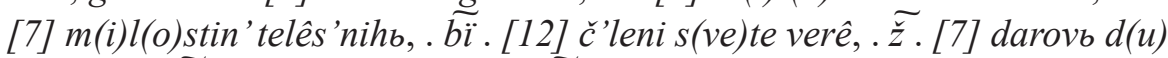

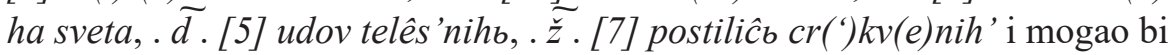
se smatrati zbornikom/obrednikom.

Njegov bi se raznolik sadržaj mogao najuže podijeliti na: molitveni dio, poučni dio i ljetopisni dio, kako ga dijeli Božo Rimac, ${ }^{15}$ a kako je u rukopisu „naslovima“ zabilježeno, sadržajno ima 39 cjelina. $^{16}$

Kao i ostali hrvatskoglagoljski tekstovi, RitKlim je značajan u našoj jezičnoj i kulturnoj povijesti, u istraživanju jezičnih osobitosti (staro)crkvenoslavenskoga jezika, ali i kao etnografski, duhovni i kulturološki spomenik.

13 BRČIĆ (1881: 162) je izračunao da je Klimantović na rukopisu radio deset godina i osam mjeseci.

14 O ovom su zborniku više pisali sljedeći autori: I. B(E)RČIĆ (1881: 161-163), I. MILČETIĆ (1911: 95-100; 1955: 93-128), S. IVANČIĆ (1910; 1911: 3-12), R. STROHAL (1915: 49-51, 103, 126, 128-129, 221), J. L. TANDARIĆ (1980: 1993), I. MULC (2004: 637-646; 2005: 311-319), I. SRDOČ-KONESTRA, S. LAJŠIĆ (2008: 75-95), K. ŠTRKALJ-DESPOT (2009: 123-146), P. RUNJE (2012, 2015).

15 Podatak je preuzet iz RUNJE 1998: 74, gdje se autor poziva na Božu Rimca i njegov diplomski rad (B. Rimac, Treći samostanski red Sv. Franje u Hrvatskoj i glagoljica, diplomski rad, Zagreb 1976. Taj se rukopis nalazi u Knjižnici franjevaca trećoredaca u samostanu sv. Mihovila u Zadru).

16 Vidi LOZIĆ KNEZOVIĆ 2010. 


\section{O grafijskim osobitostima RitKlim}

Ovdje ćemo pregledno ponuditi nekoliko karakterističnih grafijskih obilježja RitKlim-a, koji je pisan „lijepom sitnom uglatom glagoljicom“"17, pravilnim slovima. Za uvid u grafijsko stanje RitKlim-a može se istaknuti da je slovo j, kako je i uobičajeno u hrvatskoglagoljskim tekstovima, napisano s očicom udesno. Uglavnom se pojavljuje u brojevnoj vrijednosti $(=8)$, a jednom kao skraćenica za riječ zělo u kraćenju suspenzijom na prvo slovo - $i / / d(u)$ ša moê s'mete se •中. (84). Kada riječ zělo nije kraćena, slovo \$ zamijenjeno je slovom Ba, kao npr. zelo $(84 \mathrm{v})$, zêlo $(85 \mathrm{v}) .^{18}$

Spljoštena inačica granatoga $m$, takozvana ,tvrđava“, pojavljuje se u Zborniku

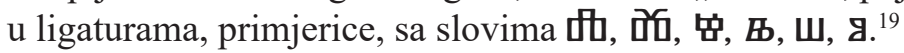

Slovo 뽀 se u Zborniku očekivano ne pojavljuje u glasovnoj ulozi, već samo u brojevnoj vrijednosti $(=700)$. Istovjetnost glasovne vrijednosti onoj slova $\mathbf{a}$ najbolje je potvrđena primjerima prefiksa/prijedloga ot('/b) koji je uvijek pisan slovom $\mathbf{9}$.

Kako je ovdje riječ o mlađem rukopisu iz vremena kada su slova 뺑 (î) i 포 (i) u hrvatskoglagoljskim tekstovima rijetkost,${ }^{20}$ treba spomenuti da su oba zabilježena u Zborniku. U brojevnoj vrijednosti (=10) potvrđeno je slovo 回 $(i)^{21}$, dok je slovo 思 (î) zabilježeno u glasovnoj službi i to samo jednom u riječi îzbavi (126). $\mathrm{U}$ svim ostalim primjerima ista riječ na istome mjestu ima $i$ (25 puta).

Kada govorimo o brojevnoj vrijednosti slova, u RitKlim- $u$ su slova onda kada označuju broj, kako je i uobičajeno, uvijek omeđena točkama s titlom iznad njih, ${ }^{22}$ kao na primjer:

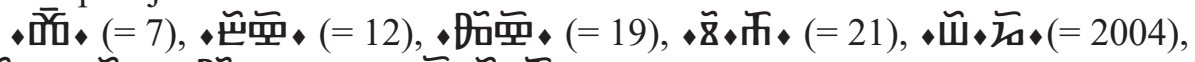

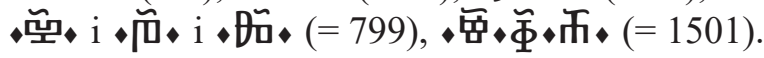

Kod viših brojeva, odnosno kod tisućica, nalazimo i one koji su rjeđe potvrđeni u hrvatskoglagoljskim tekstovima. Klimantović jednom bilježi slovo $\mathrm{I}^{23} \mathrm{u}$

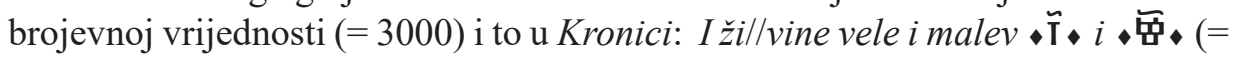
3700) (234). Također, dva je puta potvrđeno slovo $ய$ u brojevnoj vrijednosti 2000 $(229,229 v)$, koje još nalazimo u vatikanskom brevijaru Illirico 5, Moskovskom brevijaru te u Humskom, Dabarskom i 19. vatikanskom brevijaru. ${ }^{24}$

\footnotetext{
17 Vidi BRATULIĆ, DAMJANOVIĆ 2005: 214.

18 Takvo je stanje uobičajeno u hrvatskoglagoljskim tekstovima. Vidi HCJ 2014: 51.

19 MIHALJEVIĆ (2009: 297) bilježi kako se „tvrđava“ iznimno pojavljuje u ligaturama sa slovima ш i 9.

20 Vidi HCJ 2014: 53-54.

21 Od kraja 14. stoljeća 뽀 se nalazi gotovo isključivo u brojevnoj vrijednosti (HCJ 2015: 53).

22 Vidi HCJ 2014: 54.

23 U dosadašnjim istraživanjima nije pronađeno da je poluglas potvrđen u brojevnoj vrijednosti u hrvatskoglagoljskim liturgijskim knjigama (HCJ 2014: 55).

24 Vidi HCJ 2014: 55.
} 
Kod tisućica je pred slovom 安 u brojevnoj vrijednosti stavljen broj koji označuje o koliko je tisuća riječ, kao primjerice: žene negove do sada

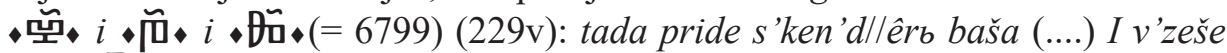

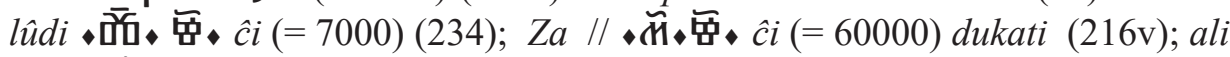

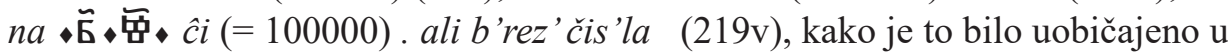
hrvatskoglagoljskoj pisarskoj praksi. ${ }^{25}$

Gramatički morfemi koji se nalaze iza slova 安 koje označuje broj tisuću mogu govoriti u prilog mišljenju da je ovakve brojeve bilo običnije pisati riječju, a ne brojkama, ${ }^{26}$ iako takve morfeme nekada nalazimo i kod jedinica, najčešće kod

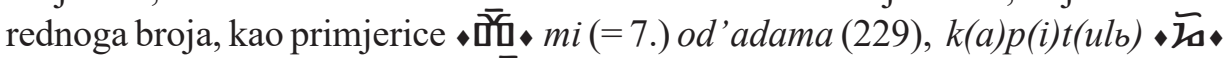

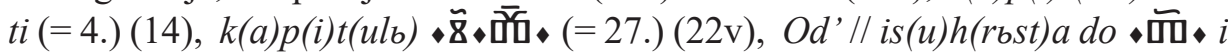
$\bullet \hat{P} \bullet i \bullet \hat{f}$. no $(=371)$ l(e) to (230) itd. U prilog tomu može stajati i primjer gdje

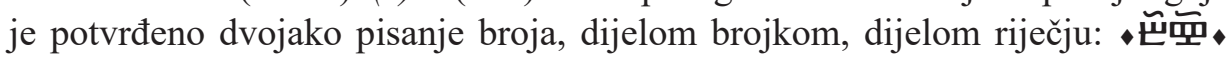
tisuĉi $(=12000)(163 \mathrm{v}) .^{27}$

Interpunkcijskih znakova u RitKlim-u ima nekoliko. Najčešći je takav znak točka po sredini retka. Dvotočka se u rukopisu nalazi 8 puta i ima istu ulogu kao i točka. Kako je bilo i uobičajeno, točka često omeđuje manje sintaktičke dijelove rečenice ili njezine intonacijske cjeline. ${ }^{28}$ Točaka je u ovom rukopisu najviše četiri, raspoređenih u obliku romba. U tim se slučajevima krajnja desna proteže u kraću ili dužu kvačicu nalik na uglatu titlu kakvu nalazimo u tekstu kod kraćenih riječi ili brojeva, na početku zavinutu prema gore, a na kraju poteza prema dolje. Četiri točke koje završavaju titlom, ali i samu titlu često nalazimo na mjestima gdje je ostalo nešto neispisanoga prostora na kraju retka. Osim toga, četiri točke koje ,završavaju“ titlom nalazimo i u Plaču gospoe prije upravnoga govora, primjerice: ovo b(la)ž(e)na gos 'poê govori iv(a)nu. // i marii man'daleni . i jinimb - : - // Man'dalêno . i jivinane. // družbo d'raga . moe rane . (29v). Na isti je način izduljena i krajnja desna točka kod trotočke, što je zabilježeno samo jednom nakon naslova, na kraju retka: Na vičeri bl(agoslo)viti s'tolb : •- // Bl(agoslo) $v(i)$ te . bl(agoslo)v(i)te . (8).

Ponekad se početak rečenice ili manjih cjelina označuje većim slovom koje svojom visinom ne izlazi iz slovnoga retka i koje nije posebno ukrašeno, osim što je ispunjeno crvenom bojom. Takva slova nalazimo na početku, ali i ,unutar“ slovnoga retka. Osim velikih slova, u Zborniku nalazimo i inicijalna, stilizirana slova koja uvijek stoje na početku retka te zauzimaju dva do sedam slovnih redaka, svojim oblikom uglavnom obla, a ukrašena viticama, listićima, odnosno laticama

\footnotetext{
25 Vidi Isto: 54 .

26 Vidi Isto.

27 Vidi Isto.

28 Vidi Isto: 57.
} 
koje se protežu duž margina. Kada se inicijal nalazi na početku posljednjega retka na stranici, onda on počinje u svome retku, ali se proteže gotovo do dna stranice.

Znak U Zborniku je zabilježen 144 puta, i to na početku novoga teksta, obreda ili npr. pojedinih glava u zapovijedima, kako je i uobičajeno u rubrikama ${ }^{29}$.

Znak + u Zborniku se nalazi 113 puta, na mjestima gdje je potrebno rukom učiniti znak križa ili blagoslov, npr.: Vime o(tb)ca.$+I s(i) n a .+I d(u) h a$ s(ve) $t(o g) a . / /+A m(e) n b$ (223), a nekada je znakom prekinuta i sama riječ, npr.: $B l(a g) o+($ slo $) v i$ (29).

Kada je u Zborniku ispušten dio teksta, uglavnom je korišten znak ^ $\mathrm{s}$ kružićem iznad njega ${ }^{\circ}$ na mjestu gdje bi taj tekst trebao stajati. Ispušteni dio teksta ispisan je na dnu ili na vrhu stranice, ponovno označen istim znakom. Na stranici $185 \mathrm{v}$ nalazimo ispušten tekst, ali je on samo dopisan na lijevoj margini, lijevo od teksta, bez posebnoga označavanja. Zgodan je primjer sa stranice $24 \mathrm{v}$ kada se taj znak nalazi na margini uz riječ neĉu kao da je ona ispuštena u drugomu retku, ali se u drugomu retku već jednom nalazi ista riječ, pa pretpostavljamo da je tu riječ o pogrešci.

Dvije okomite crte ispunjene crvenom bojom dno kojih se nastavlja vodoravnom linijom $(\underline{I I})$ nalaze se na mjestima gdje bi trebalo napisati manji dio teksta ili dio riječi iz prethodnoga slovnog retka, nakon kojega dolazi nova cjelina. $\mathrm{Na}$ tim mjestima redak započinje novom cjelinom, označenom ili velikim slovom ili inicijalom, a unutar retka se nakon oznake $\underline{I I}$ dodaje preostali dio teksta iz prethodnoga slovnog retka, npr.:

dên'jii ili v'pit'ji. ne mogu mu nau

Čet'vrtu moĉb ima s(ve)ta mi $\underline{I I}$ diti.

sa . k(a)ko govori s(ve)ti avgustin'. da (217v)

Takvom se rješenju pribjegnulo kako bi nova cjelina mogla započeti na početku retka.

Dakako, riječi se u Zborniku krate titlom. Ona je kraća ili duža; na početku poteza u oštrom kutu zavinuta prema gore, a na kraju mekše i oblije prema dolje. Zabilježeni su svi poznati načini kraćenja riječi: suspenzijom, kontrakcijom, nadrednim pisanjem slova, ligaturama, kao i kombinacijom navedenih načina. ${ }^{30}$

U Zborniku su riječi suspenzijom kraćene samo na prvo slovo riječi i na nekoliko prvih slova. To su primjeri kao: imenice slovo i sinb - $\widetilde{\mathrm{s}}$, treće lice jednine glagola biti $-\widetilde{\mathrm{e}}$, osobna zamjenica $j a-\widetilde{\hat{\mathrm{e}}}$, imenica $\operatorname{bog}_{b}-\widetilde{\mathrm{b}}$, imenica $d u h b-\widetilde{\mathrm{d}}$. Nailazimo i na to da je na prvo slovo kraćena čitava sintagma koja je razumljiva iz okoline jer je u susjednim recima napisana u punom obliku, kao npr. u pokornim psalmima sintagma za nasb $-\widetilde{z}$. Na dva prva slova kraćene su, na primjer, imenice antifonb - an i psalbmb - $\widetilde{\text { ps}}$, što je i inače često u pisarskoj praksi, ${ }^{31}$ ali,

29 Vidi HCJ 2014: 58

30 Vidi Isto: 59.

31 Vidi Isto. 
primjerice, i sintagma moli za nasb - $\widetilde{\text { mo, }}$ kojoj je značenje razumljivo iz okoline jer se ponavlja. Kontrakcija je dosta zastupljena kao oblik kraćenja i pritom su obično iz riječi ispušteni samoglasnici, kao npr.: $\widetilde{\text { pmlui }}{ }^{32}$ - pomilui, $\widetilde{k k o}-k a k o$, $\widetilde{\mathrm{zm}} \mathrm{l}^{33}$ - zemĺa, mIte - molite. Pisanjem nadrednih slova kraćen je npr. prijedlog/ prefiks $o t-\mathrm{o}^{\mathrm{t}}$, imenica antifonb $-\widetilde{\mathrm{a}^{\mathrm{n}}}$, imenica beršb $-\widetilde{\mathrm{br}^{\check{s}}}, \widetilde{\mathrm{b}^{s}}$, imenica rêśponb $-\widetilde{\mathrm{re}^{s}}$, imenica $p s a l b m b-\widetilde{p^{s}}$, imenica pêsanb $-\widetilde{\hat{p e ̂}^{s}}$. Ligature su također česte u Zborniku i ima ih horizontalnih, kao npr.: $t v, p l, g o, z l \hat{u}$ i vertikalnih, kao npr.: $p o, p r, m l^{34}$, $t r$, ali i onih kombiniranih, kao npr.: $z m l$ (m je „tvrđava“). Ima ih adekvatnih, kao npr.: go, ho, $v l$, ali i neadekvatnih, kao npr.: ili, zr, gl, lûd.

Sveukupno, grafijska obilježja RitKlim-a odražavaju stanje u mlađim hrvatskoglagoljskim tekstovima. Osnovna analiza RitKlim-a temelji se na nekim osobitostima na dvjema jezičnim razinama: na fonološkoj jer je u njoj bio najsnažniji utjecaj govornoga čakavskoga idioma na hrvatski crkvenoslavenski jezik ${ }^{35}$ i na leksičkoj, s obzirom na to da je leksik u svim jezičnim zajednicama sustav najotvoreniji promjenama, u neprestanoj mijeni, u kojemu su vidljivi i izvanjezični i unutarjezični utjecaji na njegove promjene pa, između ostaloga, i oni vidljivi u fonologiji.

\section{O fonološkim osobitostima RitKlim-a}

Na fonološkoj je razini naglasak stavljen na pitanja o kojima je potrebno dalje tražiti nova rješenja, nuditi nova argumentiranja ${ }^{36}$ Naglasak je, kako to pri obradi Akademijina brevijara nudi i Šimić (2014), stavljen na određene samoglasnike, suglasnike i suglasničke skupine, odnosno načine bilježenja znakova za jerove, na pitanje jata, refleks glasa $e$, slogotvorne $r$ i $l$, pisanje đerva, slova $f$, čuvanje skupine $\check{c} r$ te alternacije $v / b$ u posuđenim riječima. Na kraju je spomenuto i nekoliko drugih fonoloških pojava koje su odraz govornoga jezika.

\section{Samoglasnici}

U RitKlim-u zabilježena su dva znaka za jerove: štapić (I) i apostrof ('). Štapić se proteže duž cijeloga slovnoga retka, a apostrof je uglati zarez napisan iznad retka nad slovom. Uz sonante $l i$ r između suglasnika, poluglas je ondje kao oznaka njihove slogotvornosti, odnosno za foneme $/ l / \mathrm{i} / \mathrm{r} /$, kao, primjerice, gl'tuniê (10), pl'ti (28v), uml'čah' (84v), nap'l'nišse (85v), h'l'mi (111), sr 'čenoga (48v), tr'novomb (49), kr'vb (54), kr'st'êne (54v), mr'knu (59v), ûtr'ni (84).

\footnotetext{
32 m je „tvrđava“.

33 m je ,tvrđava“.

34 m je ,tvrđava“.

35 Vidi HCJ 2014: 78.

36 Vidi DAMJANOVIĆ 1984: 58.
} 
Osim toga, poluglas nalazimo i na mjestima redukcije samoglasnika unutar sloga, što je odraz utjecaja govornoga jezika, kao, primjerice, pril pelprêl'pe $(87 \mathrm{v}$, $109 \mathrm{v})$, gl'bini (108v). Neke su riječi zabilježene i bez znakova za jerove, kao, primjerice, is 'plni (109), naplni (5), ûtrne (128v), ûtrnu (17v), trnovb (51v), zadržal' $(17 v)$, gdje je vidljivo i ispadanje jakoga poluglasa. Iz prethodno navedenih, ali i iz brojnih drugih primjera vidljivo je i kako se poluglas često stavljao nedosljedno na mjestima gdje su dva suglasnika susjedna, kao, primjerice, s'labos'ti (194v), t'vrdi (50), h'raniti (211). Navedeni primjeri upućuju na pomlađenost.

Što se tiče jezične pomlađenosti teksta vidljivoj u odabiru znakova za jerove, pisanje apostrofa u odnosu na štapić prevladava. Štapić se rjeđe nalazi i unutar riječi, kao u primjerima sbt'vori (114v), prišasbtie (114v), hb(rbst)ên(b)ska (123v), cr(b)kbve (123v), m(i)l(o)srbdiem' (124), i na kraju riječi, kao, primjerice, ubogimb $(2 \mathrm{v}), i m b(129 \mathrm{v})$. Na kraju je riječi štapić u odnosu na apostrof češći kod kraćenih riječi, kao, primjerice, $\widetilde{d n b}(84 \mathrm{v}), \widetilde{h m}$ b gmb $\widetilde{n s ̌ i m b ~}$. amnb . $(129 \mathrm{v})$, iako i na kraju kraćenih riječi pod titlom nalazimo apostrof, kao, primjerice, iz $\overline{b v i t}$ ' $(88 \mathrm{v}), m \bar{l}_{s t}$ ', $(129 \mathrm{v})$, stit' (130). Pretpostavljamo da su tome razlozi estetske i grafijske prirode.

Kod prijedloga $v b$ provodi se vokalizacija, iako je u RitKlim-u više potvrda prijedloga $v$ 's poluglasom. Nevokalizirani oblik prijedloga $v b$ pojavljuje se, iako u manjem broju i pred riječima koje započinju sonantom $v$, kao, primjerice, $v$ ' večer' (191v), v'vrat (204v). U tim je slučajevima uvijek apostrof. U većoj se mjeri kod prijedloga $v b$ pred riječju koja počinje sonantom $v$ provodi vokalizacija poluglasa, kao, primjerice, va v'sems (55), va v'sihb (55v), va vikb (61), va vrata (110). U najmanjem je broju primjera potvrđen prelazak $v b>u$, kao, primjerice, u sebe (192), u boga (4v), u s'vit' (14), u koga (22). Takvo je stanje uobičajeno u hrvatskoglagoljskim rukopisima. U slabom je položaju u manjem broju primjera vokaliziran poluglas u prijedlogu odb < otb, ali takva su mjesta u gotovo svim slučajevima ispred riječi koja počinje sonantom $v$ u oblicima zamjenica $v b s b /$ vbsêkb s neprovedenom metatezom, kao, primjerice, oda v'sihb, oda v(')se, oda $v(')$ sake i tumačimo ih artikulacijskim razlozima pred suglasničkom skupinom teškom za izgovor. U samo jednom primjeru u istom položaju navedeni prijedlog nije vokaliziran - Od'vsihb $(222 \mathrm{v})$. U unutarnjim slogovima također se bilježe potvrde čakavske jake vokalnosti. Vidljivo je to u primjerima kao što su vaz 'da $(139 v)$, vapiti (78v), vas 'pet'(103v), zala (166). Međutim, iako u manjem broju, potvrđeni su i, primjerice, vbzidê $(7 \mathrm{v})$, vbzd'ržaniê $(15 \mathrm{v})$.

Među primjerima s prefiksom $v b$ - $u$ manjem su broju potvrđeni oni s vokaliziranim poluglasom, kao, primjerice, $\operatorname{Vazam}($ b) (5v), vaze (67v), vazmi (69). Brojniji su primjeri s prefiksom vb-, kao, primjerice, v'zlûb'lenim' (12), v'z'metut'(108v), v'zd'vêg' (135), v'zdai (116), v'pada (202), v'pltil (159v). Najmanje je potvrda prelaska prefiksa $v_{b^{-}}>u$, kao što su, primjerice, upade $(50 \mathrm{v})$, uprašâ̂ci $i(144 \mathrm{v})$, usk'rsnul'(82). 
Znak za jat koji se nalazi iza suglasnika, a treba ga čitati kao $[j a]$, ,označen“ je znakovima za poluglase, kao, primjerice, počttenbê (54), dbêvle (71), b'ratbê (74), dbêci (74v). Znakovi zajer jesu i indikatori jotacije, kao, primjerice, žit'êe (13), tbê (61v). Potvrđeni su i primjeri kada se znakovi za poluglase nalaze ispred znakova za samoglasnike $e$ i $i$ kod imenica s dočetkom -je ili -ji, kao, primjerice, dobit'e (19v), s(')pasen'e (48), z'grišen'e (53), s'toên'i (102). Poluglas se u navedenoj poziciji nalazi i u pridjevima na -ji, kao, primjerice, bož 'imb $(170 \mathrm{v})$, bož'emb $(71 \mathrm{v})$, $s^{\prime} \operatorname{tar}^{\prime} i(70 \mathrm{v})$ te na mjestu praslavenskoga *dj kao u primjeru pot'vr'ena $(230 \mathrm{v})$.

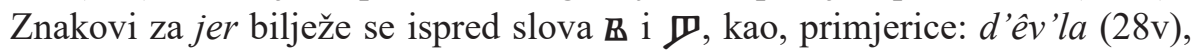

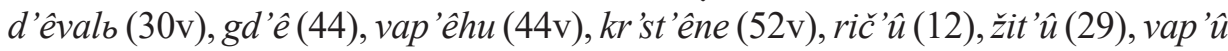
$(45 \mathrm{v})$, vap' $u \hat{c} i(50 \mathrm{v}), s^{\prime} t v o r e n ' \hat{u}(62 \mathrm{v})$ kada označuju ,posebno $i$ koje se reducira u okolini ' $j+$ samoglasnik'“, ${ }^{37}$ što je indirektno označivanje jotacije.

Fonološki položaj jata, ,jedan je od najtežih problema u fonologiji hrvatskoga crkvenoslavenskoga jezika“. ${ }^{38} \mathrm{U}$ RitKlim-u nalazimo zamjene jata sa $e$ i sa $i$, što se i očekuje s obzirom na područje na kojemu je RitKlim napisan i na fra Šimunov materinji ikavsko-ekavski srednjočakavski dijalekt zadarskih otoka, ${ }^{39}$ osobito stoga što se on smatra i autorom pojedinim dijelovima, a ne tek prepisivačem. Jat se pojavljuje ondje gdje mu je po etimologiji mjesto, kao, primjerice, lêt ' (33v), rêšiti (33v), ali nalazimo i primjera kao što su s'vêto (68), vêcera (110). Zabilježene su zamjene jata samoglasnikom $i$, kao, primjerice, miseca (33v) $p\left({ }^{\circ}\right)$ ropovidalb (34), nigovala (63), grihb(') (174), riči (163), s'vitbloi (235) i samoglasnikom e, kao što su primjeri črezb (33v), mes to (35), predb (35), letb(') (95v, 226v), delb (235), sve u skladu s pravilom Jakubinskoga i Meyera. Odstupanja od navedenoga pravila javljaju se u primjerima kada nalazimo ikavski refleks jata umjesto ekavskoga, kao npr. vridna (218v), nedilû (184v), S'povid' (177v), pripovidanie (196). Nadalje, nalazimo ekavski refleks umjesto ikavskoga, kao, primjerice, več'nihb (185), več'no (219v), ali je ista riječ većinom zabilježena s jatom. Dvojne potvrde nalazimo i kod primjera kao što su zapovêdi $(32 \mathrm{v})$ i zapovid' (62), sbvêt'lostb (149v) i s'vital' (66v), vêki (70) i vika (79v). Osim toga, nalazimo i primjere s ikavskim i ekavskim refleksom jata, ali i bez promjene kod riječi iz istoga korijena, kao, primjerice, delo (218), dila (67) i dêla (75), sedut' (145v), sidim' '(98) i sêdut' (133v). Zanimljiv je primjer imenica večerê s jatom na pogrešnome mjestu, npr. vêčeraše (47) i s prelaskom $e>i$, npr. vičera (38), vičeri $(194 \mathrm{v})$, što je hiperikavizam, odnosno fonološka čakavska pojava zatvaranja samoglasnika $e$. Čitanje slova $\boldsymbol{B}$ na početku riječi i iza znakova za samoglasnike kao $[j a]$ potvrđeno je i u RitKlim-u primjerima s dvoslovom $\hat{\jmath} a$ umjesto $\hat{e}$, kao, primjerice, $\hat{\jmath} a(25), t^{\prime}$ voja $(57 \mathrm{v}), b^{\prime}$ 'rat' $\hat{a} a(51)$.

\footnotetext{
37 Vidi Isto: 70.

38 Vidi Isto: 71.

39 Vidi MARKOVIĆ 2011: 316.
} 
Prednjojezični nazalni samoglasnik $e$ u postpalatalnom položaju nakon $j, \check{c}, \check{z}$ uglavnom se reflektira vokalom $a$. Ta je promjena tipična za čakavštinu, ${ }^{40}$ prisutna je u nekim štokavskim govorima, ${ }^{41}$ ali i u nekim kajkavskim moslavačkim govorima. ${ }^{42} \mathrm{U}$ RitKlim-u je potvrđen dvojak odraz samoglasnika $e-\mathrm{i} a$ i $e$. Kod slijeda je, imenica jęzikb uvijek je napisana s jatom, kao, primjerice, êzika (19), êzikom' (200), jednako kao i glagol prijęti, za koji u RitKlim-u nalazimo, primjerice, priêti $(179 \mathrm{v})$. Kod slijeda $\check{c} e$, prilog često potvrđen je s odrazom $a$, primjerice čas to $(177 \mathrm{v})$, čas 'ta (183). U osnovama čęt- odraz je dvojak, i a i e, kao u primjerima počaše (8), počati (23v), poča (45v), ali, samo u Kronici, i početa (230v). U osnovama žęd-odraz je $e$ u primjerima kao što su V'žeda (104v), žedaet' (104v), ali je potvrđeno i $e>a$, kao, primjerice, žainoga (176). Samoglasnik $e$ u osnovama čęst- također ima dvojak odraz, kao u primjerima pričes 'tnik' (187), pričest'nici (205v), ali nalazimo i čas to (177v). Mihaljević (HCJ 2014: 78) navodi kako je odraz a rijedak u osnovama žęd-, čęt- i čest-. Takvi su primjeri dvojnosti, kako navodi Moguš (2010: 38), hrvatska posebnost, prisutni i u starijoj hrvatskoj književnosti čakavske osnovice, a pitanje je, navodi Damjanović (1984: 68), je li to posljedica utjecaja drugih hrvatskih govora na čakavski. U ostalim pozicijama samoglasnik e realizira se kao $e$, kao, primjerice, ime (38), k'nezb $(231 \mathrm{v})$, redb $(14 \mathrm{v})$, pinezi $(19 \mathrm{v}), s^{\prime}$ veti $(65 \mathrm{v})$.

Pitanje, odnosno način bilježenja slogotvornih $r$ i $l$ u hrvatskoglagoljskim tekstovima višestruk je, a takvo je stanje i u RitKlim-u. Primjeri sa znakom za jer najčešći su. U većem broju nalazimo bilježenje u obliku likvid + jer, što odgovara načinu pisanja u starocrkvenoslavenskim tekstovima i starijim tekstovima hrvatskoglagoljske tradicije ${ }^{43}$. Jer je najčešće napisan apostrofom. Tako nalazimo, primjerice, Vr'tlar (82v), gr'lo (10), žr 'tvi (167, 169v), pl'ti (28v), s'vr'šitb (94), umr'lo (68). Osim toga, primjećuje se u manjem broju potvrda i bilježenje jera ispred $r$ ili $l$, što se u hrvatskoglagoljskim tekstovima smatra pisarskom manirom, odnosno čuvanjem tradicije ${ }^{44}$, pa je tako potvrđeno, primjerice, $p^{\prime} l k b$ (45), p'ltb (3v), p'lteno (9v), t'rplaše (78v), T'rnbemb (61), T'v'rdimb (62). Nalazimo i primjere s izostankom bilo kakvog znaka, bez pratećeg znaka za jer ${ }^{45}$ ili vokala, kao, primjerice, žrtvu (166), utvrdils (85), črno (45v). Uz navedene, u RitKlim-u ima i primjera s bilježenjem $r+V$ na mjestu poluglasa, kao, primjerice, d'rivo (209v, 217v), driv' (204v), c'rik'vene (192), crik've (103). S obzirom na vrijeme nastanka teksta, očekivani su primjeri sa zamjenom slogotvornoga $l$ sa

\footnotetext{
40 MOGUŠ 1977: 35 prenosi kako P. Ivić s punim pravom prelazak $e$ > a uključuje u „stožere čakavske genetičke individualnosti“".

$41 \quad$ Vidi DAMJANOVIĆ 1984: 67.

42 Vidi npr. CELINIĆ 2010: 58.

43 Vidi ŠIMIĆ 2014: 26; HCJ 2014: 69.

44 Vidi HCJ 2014: 69.

45 Najstarije su potvrde iz Londonskog fragmenta brevijara iz 13. stoljeća (HCJ 2014: 69).
} 
$u^{46}$. Potvrđeno je tako, primjerice, Gutunioms (174v), dugo (172), Puteni (193), suzami (124), sun'ce $(59 \mathrm{v})$.

\section{Suglasnici}

Slovo HP se u RitKlim-u javlja na mjestima uobičajenima u hrvatskoglagoljskoj pisanoj tradiciji. Nalazimo ga na mjestu grčkoga i latinskoga $g$ ispred prednjega samoglasnika u stranim riječima ${ }^{47}$ kao, primjerice, $e(v a n) \hat{\jmath}(e) l i e \hat{e}$ vanj(e)lis ti (44), a kao refleks praslavenske skupine $* d j^{48} \mathrm{u}$ primjerima poput $u t^{\prime} v r^{\prime} \hat{j} e n i i(111 \mathrm{v}), v i \hat{j} b$ (48), vij̄te (50v), saziji i (86v). Tri su grafijska rješenja pisanja praslavenske skupine $* d j^{49}$ : tradicionalno 预凹b, prema čakavskom izgovoru pisanje $\boldsymbol{H P}$ i pisanje samo susjednih samoglasnika. ${ }^{50} \mathrm{U}$ RitKlim-u nalazimo sva tri, s tim da najviše primjera nalazimo s pisanjem samo susjednih samoglasnika. Tako je, primjerice, potvrđeno: dažd' (4), prêžde (4v), v'raždênici (64); vij̄b (48), vî̄'te (50v); naslaeniemb (173), tuimb (144v), roenie (16), gospoe (235v), osuena (48v), s'lae (196v). ${ }^{51}$

Premda se đerv među dvama suglasnicima od koji je drugi $e$ ili $i$ te na početku riječi ispred $e$ najčešće ne bilježi, ${ }^{52}$ nalazimo, primjerice, je (164v), jeoni (125), lucije (112v), dok ispred samoglasnika $o$ nalazimo različite primjere bilježenja, kao, primjerice, brat'jo (79v), b'ratiom' (87).

U hrvatskim crkvenoslavenskim tekstovima sporan je samo fonološki položaj slova $\Phi$. Njegova je glasovna vrijednost stabilna. ${ }^{53}$ Sve do sredine 14. stoljeća bilježi se samo u stranim riječima, ali, kako je rubno u sustavu, i ondje se zamjenjuje sa $\mathbf{\square} .{ }^{54}$ Iako je RitKlim mlađi rukopis u kojemu se slovo $\Phi$ javlja često, bilježimo njegovu zamjenu znakom za $p$, primjerice, u posuđenici paraona $(125 \mathrm{v})$ te u imenu Judina sina parêsa (213v), Parês' (213v). Također, dvojako su zabilježeni oblici glagola ufati - i sa $f$ i sa $p$ - pa nalazimo ufaût' $(7 \mathrm{v})$, ufati (6), ali

46 KUZMIĆ 2009: 415 prenosi kako je ,proces zamjene slogotvornog $l$ samoglasnikom $u$ u čakavštini i štokavštini okončan u 14. stoljeću“, ali da se slogotvorno $l$ bez izmjene može naći sve do kraja 15. stoljeća. Međutim, primjere sa sačuvanim slogotvornim $l$ nalazimo i danas u nekim hrvatskim govorima kao npr. u mjesnim govorima Garice, Kampelja i Risike na otoku Krku gdje se ono dosljedno čuva bez izmjene u slogotvonoj poziciji (vidi LUKEŽIĆ, TURK 1998: 38-40) te u karaševskim govorima gdje se slogotvorno $l$ čuva, ali se ostvaruje i kao šwa+l (vidi LISAC 2003: 144).

47 Vidi MIHALJEVIĆ 1986: 124; HCJ 2014: 63.

48 Vidi MIHALJEVIĆ 1986: 124.

49 Slovo $j$ na mjestu praslavenske skupine * dj prvi je put zabilježeno u Splitskom fragmentu misala s početka 13. stoljeća (HCJ 2014: 63; ŠIMIĆ 2014: 26).

50 Vidi ŠIMIĆ 2014: 26.

51 Vidi MIHALJEVIĆ 1986: 125.

52 Vidi HCJ 2014: 64.

53 Vidi Isto: 65.

54 Vidi Isto: 65-66. 
i upaêûciê $(99 \mathrm{v})^{55}$ itd. U ostalim primjerima dosljedno nalazimo slovo $\Phi$, kao, primjerice, fran 'čisku (9), furmu (25), fuštanomb (15), oficii (18), f'rat'ro [m'] $(23 \mathrm{v})$, an'tifons $(29 \mathrm{v})$. Jednako je i u imenima kao, primjerice, rafaele (90), filipê (90), fabiênê (90), kr'stoforê (90).

U RitKlim-u se dosljedno čuva stara suglasnička skupina $\check{c} r$, kao što je dosljedno čuvaju svi hrvatskoglagoljski tekstovi 15. stoljeća, što govori da promjena prelaska $\check{c r}>c r$ u čakavskim govorima do kraja 15. stoljeća nije provedena. ${ }^{56} \mathrm{U}$ RitKlim-u nalazimo potvrđeno, primjerice, črna (15), Čr'vi (79v), čr'êva (106v), črm'noe (211v). Prema zabilježenim primjerima čuvanja ove stare čakavske suglasničke skupine, a i prema stanju u suvremenim čakavskim govorima, ta se vremenska granica može uzeti u obzir uvjetno, imajući istovremeno u vidu da je čuvanje navedene praslavenske skupine osobina i kajkavskoga dijalekta, čiji su elementi kontinuirano prisutni u hrvatskoglagoljskim (čakavskim) tekstovima, pa tako i u RitKlim-u.

Kada govorimo o alternaciji $v / b$ u RitKlim-u, ovdje ne nalazimo sustavnosti. Potvrđeni su primjeri koji čuvaju suglasnik $v$, kao, primjerice, aravs' $c i$ (4), elisav 'to (91), a i oni s promjenom u suglasnik b, kao, primjerice, babilon'sbkoe (213v). Dobar je primjer nedosljednosti u potvrdama, i s čuvanjem $v$ i s prelaskom u $b$, koje nalazimo, primjerice, kod Abrahamova imena: avraamu (112), avraam'li (138v), abraam'la (229), abraama (125v).

\section{O nekim ostalim fonološkim pojavama}

Ovdje je izdvojeno nekoliko fonoloških pojava koje su nastale pod utjecajem govornoga jezika. Pod tim utjecajem javlja se redukcija samoglasnika u inicijalnom slogu u prefiksima kao u primjerima: s'povidb (34), s'povid'nikb (183v), z'vanka (25), z'nutar' (28) itd., ali i u prijedlogu $i z$, kao npr.: z'dob're vole (182v), z'lukurana (227), z'mr'tvih'(83v), z'rima (230). Istovremeno su potvrđeni i primjeri bez redukcije, kao, primjerice, is 'povidb (119v), iz'van' (121v) te iz og'na $(164 \mathrm{v}), i z^{\prime} r a e ̂(151 \mathrm{v})$.

Također pod utjecajem govornoga jezika, potvrđena je redukcija glasa $i$, odnosno pojava sekundarnoga slogotvornog $r<r i$, u oblicima glagola prinesti/prinositi, kao, primjerice, p'rneseno (230), prnesut' (19v), prnesite (127v), prn'ês'li (161),

$\overline{55}$ HCJ (2014: 66) bilježi kako se u oblicima glagola ufati i njegovim izvedenicama smjenjuje s pv (u Pašmanskom brevijaru, Pariškom psaltiru, II. ljubljanskom brevijaru, III. vrbničkom brevijaru, Ročkom misalu, Metropolitanskom brevijaru, I. novljanskom brevijaru, Brevijaru popa Mavra i II. vrbničkom misalu) ili s pf (u I. novljanskom brevijaru).

56 Vidi HERCIGONJA 1973; DAMJANOVIĆ 1984: 74-75. Čuvanje skupine $\check{c} r$ osobina je čakavaca i kajkavaca, ali se navedena skupina čuva i u štokavskom narječju i to u slavonskom dijalektu u Podravini i Posavini, u zapadnom dijalektu kod moliških Hrvata, u vlahijskim govorima te u karaševsko-svinjičkoj oazi (vidi LISAC 2003: 17, 33, 53, 137, 144). 
prnosimb (167). Mihaljević ovu pojavu nalazi u Drugom beramskom brevijaru i navodi kako su navedeni primjeri svojstveni „današnjim srednjočakavskim i sjevernočakavskim govorima" $i$ da se pojavljuju i u drugim spomenicima nastalim na čakavskom području. ${ }^{57}$ Manjim su brojem potvrda u RitKlim-u zabilježeni oblici istoga glagola bez redukcije, kao, primjerice, Рrinošahu (156), prinesenu (129), prinesite (129), prinesut' (4), prinestb (4v).

Redukcija suglasnika $t r<t v r$ kod broja četiri uglavnom se ne provodi. Bilježi se, primjerice, čet'vrtoi (172), čet'vrti (196), čet'vrte (172), a kod imenice čet'vrtakb (5) nalazimo također jednom čet'rtakb (234v), što s obzirom na ostale primjere može značiti da je u ovom primjeru riječ o omašci i da redukcija suglasničke skupine tvr u navedenoj imenici ne odgovara govornoj praksi.

Zanimljiva je i pojava kada $k$ prelazi $\mathrm{u} h$ ispred drugoga $k$, a u literaturi se povezuje uz sjeverozapadnočakavske govore u središnjoj Istri ${ }^{58}$, kao u primjerima H'komu (19), h'koĵ' (19), lahko (118v), polah'ku (220). ${ }^{59}$

Nalazimo otpadanje dočetnoga $-i$ kao mlađu pojavu, osim što je u stihovima (Plačb gospoe) uvjetovana metrom, također je odraz govornoga jezika. Tako je u primjerima kao Sina t'neĉu. op 'ros 'titi (62), Naviĉaûîi t'. to poč 'ten'e (66v), rêc' mi s'tobomb. sad'um 'riti (58v), Slišahb gl(a)sb s n(e)b(e)se govoreĉ' 'm'ne (116).

\section{O mlađim jezičnim utjecajima u leksiku RitKlim-a}

Kao razina najotvorenija vanjskim utjecajima i neprestano u mijeni, leksik je osobito zanimljiv u proučavanju jezika. Iz njega iščitavamo mnogo više od jezičnih zakonitosti prisutnih u promatranom razdoblju i na određenom prostoru. Leksik nam pruža uvid u sociokulturološki, društveni aspekt formiranja teksta, zorno predstavlja govornokomunikacijske osobitosti govornika u vremenu i prostoru u kojemu je nastao. Konačno, leksikom i pisar sam sebe obilježava kao pojedinca, pojedinca u određenoj zajednici. Iz odabira leksema iščitavamo i nejezične signale s obzirom na odabir jednoga leksema u odnosu na drugi, danu situaciju, sklonosti, stavove, namjere, kao i svjetonazor pisca/prepisivača. Mnogo saznajemo o onome tko piše, ali i o onome za koga se piše. U tom smislu Ladislav Zgusta (1991) navodi kako se obrada leksičkih jedinica i živih i mrtvih jezika mora ponuditi u kontekstima kako bi im se odredila prava vrijednost, koja može varirati s obzirom na kontekst. To proizlazi iz toga što svaka riječ ima dvostruku prirodu, svoje značenje izvan i unutar konteksta, a jedino se u drugom slučaju može razlučiti njezino pravo značenje. Leksička višeslojnost, prisutna i u hrvatskoglagoljskim tekstovima, rezultat je sociolingvističkih čimbenika prisutnih u jeziku.

57 MIHALJEVIĆ 2011: 131.

58 Vidi MIHALJEVIĆ 2011: 131.

59 Ista je pojava prisutna i u govorima na zadarskom otočju. 
Šimić (2014: 89) navodi kako su u leksičkoj višeslojnosti hrvatskoglagoljskih tekstova najvažniji sljedeći slojevi:

- slavenski sloj

1. praslavensko naslijeđe, 2. moravski sloj, 3. ohridski i preslavski sloj, 4. kroatizmi

- strani slojevi

1. grčki sloj, 2. latinski sloj, 3. germanski sloj.

Zbornik fra Šimuna Klimantovića leksički je slojevit. Bogat je i domaćim riječima i onima stranoga podrijetla, u velikoj mjeri pomlađen, uz brojne arhaizme naslijeđene još iz vremena Velike Moravske. Osjetno se naslanja na živi govorni jezik, a sveukupna mu se leksička građa prema vremenskom i prostornom okviru može podijeliti na tri, a prema podrijetlu na 22 jezične skupine. Velik broj riječi praslavenske su i općeslavenske ${ }^{60}$.

Ovdje ćemo pozornost obratiti mlađim leksičkim slojevima. Među posuđenicama iz kasnijega razdoblja u RitKlim-u su potvrđeni latinizmi, talijanizmi, tzv. adrijatizmi, grecizmi, semitizmi, turcizmi, hungarizmi i germanizmi. Iz cjelokupnoga korpusa izdvojene su neke rijetke riječi koje nisu potvrđene u Slovníku i u Rječniku. Primjeri su to koji zorno govore o fra Šimunovoj slobodi pri interveniranju unutar teksta, slobodi pri njegovu formiranju upletanjem govornoga jezika u dijelovima koje čita svećenik i gdje nema mogućnosti zabune. ${ }^{61}$ Kroatizmi su izdvojeni kao posebna skupina, a predstavljaju mlađe hrvatske leksičke inovacije i u njima razlučujemo čakavski i kajkavski sloj, gdje često nije moguće točno odrediti kojemu od dvaju govornih jezika pojedini leksem pripada.

Upravo nas te dvije skupine kod kojih se utjecaj leksema dogodio u procesu razvoja hrvatske redakcije crkvenoslavenskoga jezika posebno zanimaju u analizi.

U navedenoj skupini posuđenica iz kasnijega razdoblja najviše je talijanizama, kao što su, primjerice, adurb, ver 'tudb, kun'for 'tivati, matrimonii, pelegrinb, super'bia, fatigb, štimati itd. Smatra se da su u sustav ušli preko čakavštine, odnosno preko živoga govora. Uz riječi slavenskoga podrijetla, talijanizmi su najzastupljeniji u RitKlim-u. Iz odabranoga korpusa izdvajamo imenicu adurb 'miris' ( $<$ tal. odore $)^{62}$, koja je jednokratnica u RitKlim-u u dijelu Naukb spovidniku. Imenica se javlja u sintagmi Ili v odil/ĉu s'tavil niki aduri (196). Dva retka ranije u istom značenju nalazimo turcizam musk (196). Imenica ar'mata 'vojska', 'oružana sila', 'velika flota' (< tal. < lat. arma, armata, armare ${ }^{63}$ javlja se dva

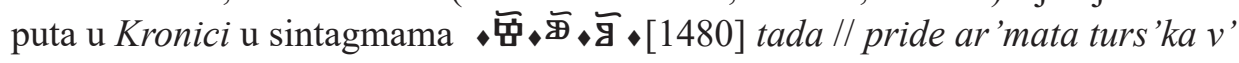

\footnotetext{
${ }_{60}$ Prema CEJTLIN 1986: 36, u kanonskim je tekstovima 9616 riječi, od toga 7838 slavenskih.

61 Vidi TANDARIĆ 1983: 80.

62 Vidi SKOK 1973: 544.

63 Vidi Isti 1971: 61.
} 
pulûu(233) i I tada im '// raz'bi fera[ri]zb ar'matu pod'fe//raromb (235). Imenica baleš tarb 'luk' ( $<$ tal. balestra, balestro $)^{64}$ jednokratnica je u dijelu Šek'ven'cie mrtvihb. U istomu retku zabilježen je i sinonim lukb u sintagmi svoi lukb nosi . $i$ baleš tarb (73v). Imenica banakb 'stol', 'drvena klupa u crkvi' $(<\text { tal. banco })^{65}$ jednokratnica je u dijelu Oficii obučeniê u sintagmi na b/lanakb prêdb ol 'taromb (29). Imenica vižitaturb 'pohoditelj' ( $<$ tal. visitatore) dvokratnica je u dijelu Rêgula pokor'nihb. Osim nje, u RitKlim-u je zabilježena i njezina istoznačnica pohoditelb u istom retku (ali i na drugim mjestima u Zborniku): potribovvanb $k^{\prime}$ voli vižitat//ura . to e(stb) pohoditela (14), Nego ako bul/de bilo v'ceni do vrimena. po // vižita turihb (14v). Imenica vizera 'maska', 'maškara' $(<\text { tal. visiera })^{66}$ jednokratnica je u dijelu Naukb spovidniku u 7. glavi o smrtnim grijesima Ili na z'le žene. Ill/i na vizerê (195). Glagol g'riš'panie 'gužvanje' (< tal. crespare) također je jednokratnica u dijelu Rêgula pokor'nihb u sintagmi brez' vsakog//a g'rišs'paniê ušivenb (15). Jednom je zabilježena i imenica dêškordia 'nesloga', 'nesklad' (< tal. discordia). U dijelu Naukb spovidniku stoji u frazi formiranoj sasvim pod utjecajem talijanskoga jezika Učiniti // dêškordiû (190).

Nakon talijanizama očekivano je najviše latinizama. Prema Tandarićevu mišljenju, starocrkvenoslavenski su se tekstovi još od najranijih početaka prilagođavali latinskim liturgijskim knjigama. ${ }^{67}$ Latinizmi su u RitKlim-u, primjerice, abitb, kvat're, lêk'cionb, og 'racia, pal'ma, regula, šek'sta, kar'te, računb, fabula itd., a među njima izdvajamo apelativ bula 'pečat', 'povelja' $(<$ srlat. bulla), zabilježen u dijelu Rêgula pokor'nihs i Ovo e(stb) bula f'ra šimuna k'lemenovica, noviji leksem u upotrebi od 16. stoljeća. ${ }^{68}$ Potvrđen je na četirima stranicama u Zborniku $(18 \mathrm{v}, 226 \mathrm{v}, 227,227 \mathrm{v}) \mathrm{u}$ sedam primjera, a izdvajamo sintagmu $A$ od'rišenie // po toi buli e(stb) ovo doli pod' bulu (226v). Imenica vicikomesarii 'podpovjerenik' $\left(<\right.$ lat. vice- + commisio) također je mlađega postanja, u upotrebi od 15. stoljeća. ${ }^{69}$ Jednokratnica je u dijelu Ovo e(stb) bula f'ra šimuna k'lemenoviça u sintagmi v' $\hat{j} / /$ ime z'gora rečenoga vicikomes//ariê $(228 \mathrm{v})$.

Kako bismo preciznije naglasili njihovu etimologiju, među romanizmima razlikujemo i tzv. adrijatizme, riječi sačuvane iz dalmatskoga i venecijanskoga jezika. Odraz su govora fra Šimunova vremena i kazuju kako živa narodna riječ prodire i u crkvene knjige. Dalmatinsko je stanovništvo sredinom 15. stoljeća bilo četverojezično: hrvatskim se jezikom služilo kao govornim unutar obitelji, dalmatski je bio društveno razlikovni jezik: plemići su ga i dalje upotrebljavali, dok

\footnotetext{
Vidi Isto: 101.

65 Vidi Isto: 105.

66 Vidi Isti 1973: 601.

67 Vidi ŠIMIĆ 2000: 94.

68 Vidi SKOK 1971: 185.

69 Vidi Isti 1972: 133.
} 
su ga pučani već bili zaboravili, latinski jezik upotrebljavao se u administraciji, a talijanski je bio jezik trgovine. ${ }^{70}$ Dalmatizmi su u RitKlim-u npr. almužst'vo, dup'lati, lan'cunb, munita, tover 'na, tum'panb, funestra itd. Iz izdvojenoga korpusa navodimo dalmatizam guster'na 'cisterna', 'čatrnja' $(<\text { dalm. *gusterna })^{71}$, jednokratnicu u dijelu Bl(agoslo)vb stola u sintagmi posla me // na kombčarb negovu guster'nu piti vodu ž nee (9). Imenica žežinb ${ }^{72}$ 'jejunij', 'veliki post' (< dalm. *jejunar) $)^{73}$ javlja se u Zborniku pet puta u dijelovima Bl(agoslo)vb stola, Naukb spov(i)dniku i Spovid. Izdvajamo tri sintagme v'kvat'rê. I/ ali v'žežini

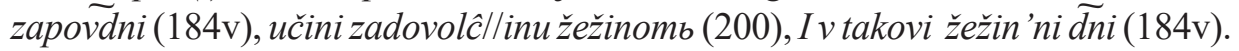
Imenica žežin b, za koju se smatra da je iz kasnoga latinskoga jezika u Dalmaciji ušla u praslavenski, a potom u hrvatski jezik, ${ }^{74}$ jedna je od najstarijih u slavenskim rukopisima, još iz vremena prvih dodira s kršćanstvom.

U latinski jezik oko 1000. godine ulazi i venecijanski jezik, i to njegova kolonijalna varijanta, tzv. veneziano coloniale, koja pripada tzv. Zapadnoj Romaniji. ${ }^{75}$ Dalmatoromanska potporodica dio je, zajedno s izumrlom albanoromanskom i uglavnom sačuvanom dako-mezijskoromanskom, tzv. Istočne Romanije. ${ }^{76}$ Venecijanizmi se javljaju kao rezultat prevlasti venecijanskoga idioma nad dalmatskim jezikom. Kao lingua franca Mediterana, kao mlađi idiom u odnosu na dalmatski, a i s obzirom na to da je razdoblje vladavine Mletačke Republike trajalo mnogo dulje nego što se dalmatski kao ostatak vulgarnolatinskoga jezika zadržao na ovim prostorima nakon dolaska Hrvata na jadransku obalu, venecijanizmi su u RitKlim-u potvrđeni većim brojem primjera nego dalmatizmi. To su, primjerice, ar'ta, ar 'tižanb, bečb, golia, duka, kaš'tigb, križb, kun'trata, manestrati, pržunb, savurb, fust'a, čava(lb) itd. Iz korpusa izdvajamo nekoliko rjeđih. Apelativ ban'dižati 'prognati', 'izgnati' (< ven. bandizzar) javlja se u dijelu Kronika u dvjema potvrdama: tada gos'poda b'netač'ka bal/n'dižaše g'roši . ki tecihu po .g. [3] so//dini . I os'maci ban'dižaše $(232 \mathrm{v}, 232 \mathrm{v})$. Apelativ bandižati potvrđen je od 16. stoljeća u Marulića. ${ }^{77}$ Imenica garofalb 'karanfil' (< ven. garòfalo) potvrđena je u dijelu Naukb spov(i)dniku i jednokratnica je Ili garofali . Ili mete. I/ Ili razliko c'vetie . (196). U našem je sustavu također od 16. stoljeća. ${ }^{78}$ Imenica

\footnotetext{
70 Vidi ŠIMUNKOVIĆ 2009: 15-16.

71 Vidi SKOK 1971: 319.

72 U Rječniku je potvrđen glagol žežinati (BrVat ${ }_{5}$, RitKlim, MVat $\left.{ }_{4}\right)$.

73 Vidi SKOK 1973: 679.

74 Vidi MULJAČIĆ 2003: 141.

75 Venecijanski se ponekad u literaturi naziva mletačkim jezikom kako bi se izbjegnulo miješanje $\mathrm{s}$ venetskim, izumrlim indoeuropskim jezikom Venetske provincije.

76 Vidi MULJAČIĆ 2003: 133.

77 Vidi SKOK 1971: 106.

78 Vidi Isti 1972: 22.
} 
daciêra 'porez', 'dažbina' (<ven. daziere) $)^{79}$ javlja se u dijelu Naukb spov(i)dniku i također je jednokratnica Ili dêsetinu // crikvenu. Ili daciêru (188). Apelativ dukatb 'mletački zlatnik' (< ven. ducato $)^{80}$ u dijelu je Oficii mrtvihb jednokratnica u sintagmi $Z a / / . \tilde{m} . \tilde{c}$. [60 000] ci i dukati (216v). Apelativ dês'perati 'očajavati' ( $<$ ven. desperare) zabilježen je u dijelu Naukb č(lovi)ku na sp(o)v(i)di, također kao jednokratnica ne bil's//amb obisilb . dês'perav'ši se (180). Venecijanizmi u RitKlim-u većinom su jednokratnice, mlađi leksemi iz govornoga jezika.

Kao posljedica diplomatskih, odnosno političkih dodira s Bosnom, a kako je osmanoturski jezik u 15. stoljeću počeo utjecati na naš idiom, potvrđeni su i rijetki turcizmi u Zborniku. Takva je, primjerice, imenica baša/bašadurb 'glavar' (< tur. $b a-)$, koja je dvokratnica u RitKlim-u zabilježena u Kronici u sintagmama pride bašal/durb tur 'ski v'zadarb (233) i pride s'ken'd/lêrb baša s'tur'ci v'h'rvate (234).

U ovom su Zborniku grecizmi uglavnom religijski, crkveni pojmovi i osobe te pojmovi iz Biblije. Dijelom se mogu smatrati latinizmima grčkoga podrijetla. Grecizmi su u RitKlim-u, primjerice, adb, anjelb, apus'tolb, arhanjelb, arhierêi, biskup', dêmunb, erêmitb/remeta, žakanb itd. Zabilježena je, primjerice, i imenica g'loza 'marginalna napomena' (< gr. $\gamma \lambda \omega ́ \sigma \sigma \alpha)^{81}$, dvokratnica u dijelu Tas 'tamen 'to u sitagmama da ne kladu g'loze ili // tumačeniê v rêguli. (27v) i čistimb zak̃nomb brezb g'lozan//iê (27v). Skok (1971: 572) navodi kako je u upotrebi od 16. stoljeća. Imenica des 'potb 'carski pokrajinski namjesnik' $(<\text { gr. } \delta \varepsilon \sigma \pi \delta ́ \tau \eta \varsigma)^{82}$ javlja se u Kronici u dvjema potvrdama: S'mrtb vul/[ka des'pota] .c . u. $\widetilde{o} . \widetilde{d}$. [1485] tada um'//ri vukb dês'potb $(233 \mathrm{v}, 233 \mathrm{v})$.

U Zadru u fra Šimunovo vrijeme hrvatski jezik (čakavski) predstavlja pitanje „socijalne unutrašnje politike“, a i pitanje „vanjske politike i diplomacije“. Vulgaris sermo, pučki narodni jezik, stoji nasuprot latinskomu koji je još uvijek bio jedini priznati jezik pismenosti. Međutim, Zadrani većinom govore samo hrvatskim jezikom i ne poznaju talijanski, koji je još uvijek bio tek pridošlica u mletačkoj službenoj korespondenciji. ${ }^{83}$

Iako je čakavski utjecaj RitKlim-a vidljiv na svim jezičnim razinama, na onoj leksičkoj u prvom redu treba spomenuti zamjenicu ča kao karakteristični lik i signal o utjecaju čakavskoga elementa na leksičkoj razini. Ona je potvrđena 94 puta. Osim toga, potvrđena je i crkvenoslavenska zamjenica čbto, uvijek u dijelovima na crkvenoslavenskom jeziku (14 puta) - ča ti činiš '. // I ča misliš'. I to ča s'povidaš' (180v). Kao čakavizam izdvajamo, primjerice, veznik ako zabilježen 156 puta, dok je crkvenoslavenski veznik aĉe zabilježen 36 puta - Da ako bi v'si

\footnotetext{
79 Vidi Isti 1971: 371.

80 Vidi Isto: 463.

81 Vidi Isto: 572.

82 Vidi Isto: 396.

83 Vidi PEDERIN 1984: 74-76.
} 
g'//risi v'tebi bili (181). Čakavski je i prilog vaz(')da potvrđen 47 puta, dok za crkvenoslavenski vbsegda nema potvrda - Vaz'da želiti dobil/ti bl(a)go ovoga s'vita (192). Čakavski glagol diti potvrđen je 29 puta, dok crkvenoslavenskoga dêti nema. Značenje je glagola diti na svim mjestima u RitKlim-u 'govoriti', 'kazati' ${ }^{4}$ - Toga se kầ . I di//mb b(og)u moi g'rihb (173). Treba spomenuti i čakavski prilog pak(') koji je potvrđen u dvama primjerima u dijelovima Plačb gos 'poe i Šek'ven'cie mrtvihb, dok je crkvenoslavenski paki zabilježen u 24 potvrde - Na n(e)besa. pak' ću poiti (65) : Paki ga pitai. Ki ar 'tǐ̌l/an'si (170). Pod utjecajem govornoga jezika u svim je slučajevima potvrđen prilog kada (113 puta), kao Kadb na križi . za te višahb (78v), a crkvenoslavenskoga kbgda nema. Crkvenoslavenska zamjenica iže (41 potvrda) zanemarivim je brojem primjera potvrđena u odnosu na hrvatske skraćene, stegnute oblike $k i, k a, k e$ (sveukupno 650 potvrda) - onomb ob 'las 'ti ku ê im//amb (203). Veznik leki Jagić smatra kasnijim ,panonskim“ ili hrvatskim unosom u crkvenoslavenski leksik. ${ }^{85}$ Veznik je leki u RitKlim-u potvrđen u osam primjera - Iže leki // c'vet'proničet' is 'tiraet'se . i otbigael/t' leki sênb (102). Čakavizmom bismo mogli smatrati i prilog načina d'raže 'skuplje', 'ljubaznije', 'ljepše' (npr. za moĉi û d'raže prodati (192v)). Kuštović (2014: 168) navodi kako navedenog priloga načina nema u hrvatskim liturgijskim tekstovima ${ }^{86}$, dok je u Slovníku potvrđen samo pridjev dražii 'skuplji', 'dragocjeniji'. Takav je i prilog mjesta dale. Kuštović ${ }^{87}$ izdvaja prilog smjera dale i navodi kako je potvrđen u Slovniku i u našim liturgijskim tekstovima, dok ga u našim neliturgijskim tekstovima nema. Nadalje navodi da kao prilog mjesta nije potvrđen ni u Slovníku i u našim liturgijskim tekstovima, a u neliturgijskima jest. Tako je i u RitKlim-u, gdje je jednokratnica, u sintagmi tada pride edna velika i čud'na // fur'tuna. ods talie i po v'soi // dalmacii . i dale (233v). Katkada se u istome dijelu RitKlim-a miješaju i crkvenoslavenski i hrvatski primjeri. Tako se npr. čakavizmi kao vaz'da i diti javljaju i u dijelovima Zbornika napisanima crkvenoslavenskim jezikom, dok se crkvenoslavenizmi kao npr. zamjenica iže i prilog paki nalaze u više potvrda u dijelovima na narodnom jeziku.

RitKlim bilježi manji broj kajkavizama koji su potvrđeni i manjim brojem primjera. U RitKlim-u ne nalazimo zamjenicu kaj, ${ }^{88}$ prema Damjanoviću ,za-

84 Usp. DAMJANOVIĆ i dr. 2004: 78.

85 JAGIĆ 1913: 199, 418.

86 U građi Rječnika potvrđen je pridjev dragb u značenju 'drag', 'dragocjen', 'predrag'. Usp. DAMJANOVIĆ i dr. 2004: 74.

87 Vidi KUŠTOVIĆ 2014: 90; Ista 2007.

88 Kajkavizmi su u književnost ušli početkom 15. stoljeća, i to u hrvatskoglagoljskim zbornicima, kao rezultat nastojanja premošćivanja dijalekatskih razlika (v. HERCIGONJA 1983: 303-385; ŠIMIĆ 2008: 346). 
štitni znak“" kajkavštine koji glagoljaš čakavac nije mogao unijeti slučajno. ${ }^{89}$ Ako uzmemo da kaj naznačuje hotimičnost, onda bismo, u njegovoj odsutnosti, mogli zaključiti da unošenje spomenute nekolicine kajkavskih leksema ipak nije bilo namjerno. Međutim, unošenje sinonima kao što je npr. špotanie i ruganie dokazuje suprotno.

Analizom razlučujemo da su kajkavizmi u Zborniku dvojakoga karaktera. Prva skupina spada u zajednički čakavsko-kajkavski leksički sloj unutar kojeg su u RitKlim-u potvrđeni, primjerice, venecijanizam kaš'tigb 'kazna' (< ven. castigo) koji Damjanović (1984: 176) smatra kajkavizmom. Potvrđen je u sedam primjera - takovu kaš'//tigu g'ladomb (162). Dijelom zajedničkoga leksika smatra se i praslavenska imenica luna koja se pojavljuje u svim trima našim narječjima. U RitKlim-u je potvrđena u četirima primjerima-otimet'se // luna. IobTdaet'od'mora do mo//ra (4v). U RitKlim-u je potvrđen praslavenski pridjev $h u d b$, kod kojega je u odnosu na Slovnik došlo do pomaka u značenju ('ubog, slab, malen, kratak, bijedan, gori'). Tri su potvrde u RitKllim-u - huda dêla . os'tavimo (75). Oblici zamjenice $g\left({ }^{\prime}\right)$ do i k'to smjenjuju se u ovom rukopisu, s tim da je oblik $g($ ')do neznatno češći. Oblik zamjenice gdo smatrao se kajkavizmom, ali se ona ipak može uzeti kao „zajedničko dobro čakavštine i kajkavštine“. ${ }^{90}$

Druga skupina pripada kajkavskome leksičkom sloju unutar koje su u RitKlim-u potvrđeni, primjerice, pridjev vekši, u četirima primjerima - Onb ki e v/lekši odb tebê (197v). Ohridizam olêi $i^{91}$ (< lat. oleum) dvokratnica je - Umastil'esi olêl/em' gl(a) vu môे $(99 \mathrm{v})$, dok je dalmatski uli znatno češći (17 potvrda). Germanizam tanacb 'ples' (< njem. tanzen) najranije je potvrđen u Novakovu misalu iz 1368. godine i sa sjevera je proširen na južne krajeve ${ }^{92}$ gdje je uz tanac u upotrebi i romanizam bal. U RitKlim-u nalazimo četiri potvrde - Ili tan'ci v' takovi d(a)ni . (195). Kajkavizam je i protobugarizam tovariš' ' $\approx$ rus. tovariščc $<$ turk.) koji je u kajkavski i u južne hrvatske govore ušao iz mađarskoga jezika. ${ }^{93}$ Imenica tovariš' je u Zborniku jednokratnica, a dvije su potvrde izvedenice tovarišs tvo - A // tovariš' negovb ki bi z'nalb (34v). Germanizam iz praslavenskoga razdoblja hiža (< germ. *hūs- (stvnjem. $h \bar{u} s))$ u Zborniku se, primjerice, u dijelu Šek'ven'cie mrtvihb iz stiha u stih smjenjuje s apelativom kuĉa-Hiža negova . v'sa sad'c'vili (70). Spomenuli smo već germanizam špotanie (< njem. spotten), jednokratnicu u Zborniku kod koje je od značenja 'šaputanje', 'izvještavanje', 'obavještavanje'

\footnotetext{
89 DAMJANOVIĆ 1984: 171.

90 Vidi DAMJANOVIĆ 1984: 163.

91 Vidi MIHALJEVIĆ 2007: 266.

92 Vidi ŠIMIĆ 2007: 363.

93 Vidi Isto: 364.
} 
u našem sustavu ostalo 'ruganje'94 - Špotanie I ruganie (189). Potvrđen je i germanizam š'koditi (< njem. Schade), jednokratnica, pravi kajkavizam koji se odatle proširio na čakavštinu ${ }^{95}$ - niš'//tar' nimb ne mogaše š koditi $(217 \mathrm{v})$. Značenjem i svime što značenje uvjetuje ovome glagolu odgovaraju glagoli uditi, štetiti, pa$k s_{t i t i}{ }^{96}$. Možemo izdvojiti i likove priloga s određenjem redoslijeda neke radnje: d'rugoč '97, tretič' i četrtič' (npr. Pop ' rci d'rugoč' (160v), Pop 'rci tretič' (160v), Pop' rci četrtič' $(160 \mathrm{v}))$, koji su danas karakteristični za kajkavsko narječje ${ }^{98}$. U Zborniku je potvrđen prilog put(')b na mjestima gdje nije neodređen broj uz opetovanu radnju (npr. po ki koli put' (192), kol//iko krat'e ki grihb učinilb. i po k//i putb (202v)).

U treću bi se skupinu uvjetno mogli svrstati leksemi za koje nije sasvim sigurno pripadaju li kajkavštini ili čakavštini. To su talijanizam tas 'tamen 'tb $(<$ tal. testaménto ${ }^{99}$, u tekstu Zbornika potvrđen šest puta - i ove riči moga tastamen'/l ta $(27 \mathrm{v})$. Semitizam šerafimb ( $<$ lat. seraphim, seraphicus $<$ hebr. serafim), jednokratica u RitKlim-u, u naš je sustav ušla latinskim posredovanjem - I v' im//e herofimb $i$ šerafimb (123v). U tekstu je Zbornika 26 potvrda latinizma šek'ven'cia (< lat. sequentia $)^{100}$, i to uvijek u ,naslovu“ teksta koji slijedi, npr. šek'ven'ciê marie man 'dalene (81v). Također je latinizam jednokratnica šek'sta ( $<$ lat. sequentia)-Prêmu. Ter'cu. Šek'stu. N//onu . (17v). I grecizam š tola, koji je u naš sustav ušao latinskim posredovanjem ( $<$ lat. stola $)^{101}$, također je jednokratnica $-i$ položi // štolu na se (117). Kod svih je primjetan prijelaz $s>\check{s}$ u stranim riječima, što je osobina kajkavštine, premda je do promjene moglo doći i pod utjecajem romanskih govora ${ }^{102}$. Ako bismo slijedili navedeni kriterij, i talijanizam beršb također bismo trebali ubrojiti među kajkavizme jer je i kod njega prisutan prijelaz $s>\check{s}(<$ lat. versus $)$.

94 SKOK 1973: 410 navodi kako je ova riječ poznata od 16. stoljeća. Međutim u hrvatskoglagoljskim zbornicima potvrđena je od 15. stoljeća, a i u jednom brevijaru s prijelaza 14. na 15. stoljeće (Vidi ŠIMIĆ 2007: 363).

95 Vidi ŠIMIĆ 2007: 362.

96 Vidi BUDJA 2004: 5.

97 Ovakav se lik priloga, kako navodi Skok (1971: 446), javlja u 15. stoljeću u čakavaca (i Marulića) i bosanskih pisaca. U građi Rječnika je prilog drugočb potvrđen u MNov, MRoč, RitKlim, CPar, CŽg, CGrš, CFat i u brevijarima BrVat, BrPm, BrLab.

98 Vidi KLINČIĆ 2012: 339-340.

99 SKOK 1973: 463 kaže da je u upotrebi od 15. stoljeća u Dubrovniku, odnosno od 1466. godine na Ugljanu. DAMJANOVIĆ 1984: 175 navodi kako bi se ova imenica eventualno mogla smatrati kajkavskom te da njezina upotreba u čakavskome ne isključuje mogućnost da je u te govore mogla doći iz kajkavskoga.

100 Vidi SKOK 1973: 284.

101 Vidi Isto: 337.

102 Vidi ŠIMIĆ 2007: 349. 


\section{Zaključak}

Zbornik fra Šimuna Klimantovića I (RitKlim) iz 1512. godine kompilacija je ritualnih tekstova s različitim obredima. Njegov pisar poznat je znanosti kao jedna od triju najznačajnijih osoba tzv. glagoljskoga humanizma i prvi je pisac triju obrednika.

Grafijske značajke RitKlim-a odražavaju stanje u mlađim hrvatskoglagoljskim

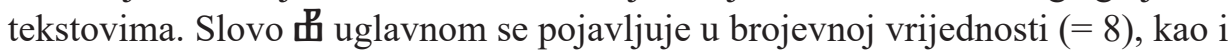
slovo 보 (=700). Slovo ㅃㅃㄹ (î) zabilježeno je jednom u glasovnoj službi. Od pojava rjeđe potvrđenih u hrvatskoglagoljskim tekstovima, npr. u brojevnoj vrijednosti, nalazimo slovo Ш $(=2000)$ i još rjeđe $\mathrm{I}(=3000)$. Riječi su kraćene titlom i zabilježeni su svi poznati načini kraćenja. Česte su i ligature gdje se pojavljuje spljoštena inačica granatoga $m$.

U rukopisu nalazimo zabilježena dva znaka za jerove: štapić (T) je zabilježen manjim brojem potvrda i u sredini (prišasbtie, crkbve, mlsrbdiem') i na kraju riječi (ubogimb, imb), dok apostrof (') prevladava u objema pozicijama (dos 'toit', od', p'sal'mi). Pomlađenost je vidljiva iz primjera bez znakova za jerove (naplni, nikim, zadržal'), gdje je vidljivo i ispadanje jakoga poluglasa, a često je i nedosljedno stavljanje poluglasa između dvaju susjednih poluglasa unutar riječi (s'labos 'ti, t'vrdi, h'raniti). Nalazimo čakavsku jaku vokalnost kod prijedloga $v b$, prefiksa $v_{b}$ - (v'večer', vazmi), a tek je nekoliko primjera prelaska $v b>u(u$ koga, u s'vit). U istom je položaju vokaliziran poluglas kod prijedloga odb $<$ otb, također u manjem broju (oda v'sihb, oda v'sake), kao i u unutarnjim slogovima (vapiti, zala, vas 'pet'). S obzirom na pitanje jata, u RitKlim-u bilježimo njegovu ikavsko-ekavsku zamjenu (nigovala, letb), prema pravilu Jakubinskoga i Meyera, ali i odstupanja od toga pravila (prominimo, večno, zapovid'). Nazalni samoglasnik $e$ nakon $j, \check{c}, \check{z}$ uglavnom se reflektira vokalom $a$, što je promjena tipična za čakavštinu (êzika, čas 'to, žedaet'), ali je prisutna i u štokavštini i u kajkavštini. Slovo $\Phi$ javlja se često, u stranim riječima (fuštanomb, an 'tifonb), ali bilježimo i njegovu zamjenu znakom za $p$ (paraona, parêsa). Čakavska je osobina i čuvanje stare suglasničke skupine $\check{c} r$ ( $\check{c} r n a, \check{c} r$ 'eva), ali je nalazimo i u nekim štokavskim govorima. U odabiru leksema iz govornoga jezika, umjesto crkvenoslavenskih, izravan je utjecaj govornoga idioma fra Šimuna Klimantovića. Tomu svjedoče mlađe posuđenice (adurb, bula, guster'na, ban'dižati, baša, des 'pot), a osobito kroatizmi gdje razlučujemo čakavizme (diti, leki, draže) i kajkavizme (kaš’tig, tanacb, hiža), koji također RitKlim povezuju uz čakavski sjeverozapad. 


\section{Bibliografija}

\section{Popis kratica}

BrLab - Ljubljanski brevijar, kraj 14. stoljeća, Ljubljana, Nacionalna in sveučilišna knjižnica, sign. Ms 161 (C 161a/2).

BrPm - Pašmanski brevijar, druga polovina 14. i 15. stoljeća, Zagreb, Arhiv HAZU, sign. III b 10.

$\mathrm{BrVat}_{5}$ - 5. vatikanski brevijar, sredina 14. stoljeća, Vatikan, Biblioteca Apostolica Vaticana, sign. Borg illir. 5.

CFat - Fatevićev zbornik duhovnog štiva, 1617. g., Zagreb, Hrvatska akademija znanosti i umjetnosti, sign. IV a 124.

CGrš - Grškovićev zbornik, 16. stoljeće, Zagreb, Hrvatska akademija znanosti i umjetnosti, sign. VII 32.

CPar - Pariški zbornik, 1375. g., Pariz, Bibliothèque Nationale, sign. Slave 73.

CŽg-Žgombićev zbornik, 16. stoljeće, Zagreb, Hrvatska akademija znanosti i umjetnosti, sign. VII 30.

MNov - Misal kneza Novaka, 1368. g., Beč, Österreichische Nationalbibliothek, sign. Cod. slav. 8.

MRoč - Ročki misal, oko 1420. g., Beč, Österreichische Nationalbibliothek, sign. Cod. slav. 4.

$\mathrm{MVat}_{4}$ - Vatikanski misal Illirico 4, početak 14. stoljeća, Rim, Biblioteca Apostolica Vaticana, sign. Borg. illir. 4.

RitKlim - Klimantovićev zbornik (obrednik), 1501. - 1512. g., Zagreb, Samostan franjevaca III. reda Sv. Ksaver.

\section{Literatura}

BRATULIĆ, Josip, Stjepan DAMJANOVIĆ. 2005. Hrvatska pisana kultura, I. svezak: VIII.-XVII. stoljeće. Križevci-Zagreb: Veda.

BRČIĆ, Ivan. 1881. Njekoliko staroslavenskih i hrvatskih knjiga što pisanih, što tiskanih glagolicom, kojim se u skorašnje doba u trag ušlo. Rad JAZU 59: 158-185.

BUDJA, Jurica. 2004. Etimologija glagola (na)uditi. Filologija 43: 1-9.

CEJTLIN, Ralja Mihajlovna. 1986. Leksika drevnoebolgarskih rukopisej X-XI vv. Sofija: Izdatelıstvo bolgarskoj Akademii nauk.

CELINIĆ, Anita. 2010. Govor mjesta Posavski Bregi kraj Ivanić-Grada. Kaj: časopis za književnost, umjetnost $i$ kulturu XLIII/4: 47-65.

CURTIUS, Ernst Robert. 1988. Europska književnost i latinsko srednjovjekovlje. 2. izdanje. Zagreb: Naprijed.

DAMJANOVIĆ, Stjepan. 1984. Tragom jezika hrvatskih glagoljaša. Zagreb: Hrvatsko filološko društvo.

DAMJANOVIĆ, Stjepan. 2000. Filološki razgovori. Zagreb: Hrvatska sveučilišna naklada. 
DAMJANOVIĆ, Stjepan i dr. 2004. Mali staroslavensko-hrvatski rječnik. Zagreb: Matica hrvatska.

HERCIGONJA, Eduard. 1973. Kajkavski elementi u jeziku glagoljaške književnosti 15. i 16. stoljeća: (prilog istraživanju kontinuiteta hrvatskog književnog jezika). Croatica 4/5: $169-245$.

HERCIGONJA, Eduard. 1983. Nad iskonom hrvatske knjige. Zagreb: Liber.

HERCIGONJA, Eduard. 2004. Na temeljima hrvatske književne kulture, Filološkomedievističke rasprave. Zagreb: Matica hrvatska.

HCJ = Hrvatski crkvenoslavenski jezik. 2014. Prir. Milan Mihaljević. Zagreb: Hrvatska sveučilišna naklada, Staroslavenski institut.

IVANČIĆ, fr. Stjepan. 1910. Povijestne crte o samostanskom III Redu sv. O. Franje po Dalmaciji, Kvarneru i Istri i Poraba glagolice u istoj redodržavi, sa prilozima. Zadar: Odlikovana tiskarna E. Vitaliani.

IVANČIĆ, fr. Stjepan. 1911. Nešto o hrvatsko - glagolskim piscima samostanskih Trećoredaca. Zadar: Brzotiskom „Katoličke hrvatske tiskarne“.

JAGIĆ, Vatroslav. 1913. Entstehungsgeschichte der Kirchenslavischen sprache. Berlin: Wiedmannsche Buchhandlung.

KLINČIĆ, Ivana. 2012. Tvorba riječi s brojevnim značenjem u hrvatskom kajkavskom književnom jeziku. Rasprave Instituta za hrvatski jezik i jezikoslovlje 38/2: 327-355.

KUŠTOVIĆ, Tanja. 2007. Prilozi mjesta i smjera u staroslavenskom jeziku i hrvatskoglagoljskim tekstovima 14. i 15. stoljeća. Slovo 56-57: 269-286.

KUŠTOVIĆ, Tanja. 2014. Prilozi u hrvatskoglagoljskim tekstovima. Zagreb: Matica hrvatska.

KUZMIĆ, Boris. 2009. Jezik hrvatskih srednjovjekovnih pravnih spomenika. U Povijest hrvatskoga jezika, 1. knjiga: Srednji vijek, ur. Ante Bičanić, 405-455. Zagreb: Croatica.

LISAC, Josip. 2003. Hrvatska dijalektologija 1. Hrvatski dijalekti i govori štokavskog narječja i hrvatski govori torlačkog narječja. Zagreb: Golden marketing - Tehnička knjiga.

LOZIĆ KNEZOVIĆ, Katarina. 2010. Leksik Klimantovićeva zbornika iz 1512. godine. Doktorska disertacija, Filozofski fakultet Sveučilišta u Zagrebu.

LUKEŽIĆ, Iva, Marija TURK. 1998. Govori otoka Krka. Crikvenica: Libellus.

MALIĆ, Dragica. 1972. Jezik najstarije hrvatske pjesmarice. Zagreb: Hrvatsko filološko društvo.

MARKOVIĆ, Irena. 2011. Jezični utjecaji i promjene u suvremenom govoru Zadra. Croatica et Slavica Iadertina VIII/II: 313-335.

MIHALJEVIĆ, Milan. 1986. O glasu $j$ i načinima njegova bilježenja u tekstovima hrvatske redakcije crkvenoslavenskog jezika. Slovo 36: 123-139.

MIHALJEVIĆ, Milan. 2007. Leksik najstarijih hrvatskoglagoljskih fragmenata. Studia Slavica Hungarica 52/1-2: 263-272.

MIHALJEVIĆ, Milan. 2009. Hrvatski crkvenoslavenski jezik. U Povijest hrvatskoga jezika, 1. knjiga: Srednji vijek, ur. Ante Bičanić, 283-349. Zagreb: Croatica.

MIHALJEVIĆ, Milan. 2011. Bilješke o jeziku Drugoga beramskoga brevijara. Tabula 9: 126-139. 
MOGUŠ, Milan. 1977. Čakavsko narječje, Fonologija. Zagreb: Školska knjiga.

MOGUŠ, Milan. 2010. Povijesna fonologija hrvatskoga jezika. Zagreb: Školska knjiga.

MULJAČIĆ, Žarko. 2003. O dalmatoromanizmima u Marulićevim djelima. Colloquia Maruliana XII: 131-143.

PEDERIN, Ivan. 1984. Mjesto i uloga hrvatskog jezika u mletačkom Zadru i mletačkoj diplomaciji. Jezik 31/3: 73-79.

RJEČNIK = Rječnik crkvenoslavenskoga jezika hrvatske redakcije, I. svezak, A - vrêdь, sv. 11-20. Zagreb: Staroslavenski institut, od 1991.

RUNJE, Petar. 1998. O knjigama hrvatskih glagoljaša [Djela Instituta za ekumensku teologiju i dijalog Katoličkog bogoslovnog fakulteta u Zagrebu, knj. 2]. Zagreb: Kršćanska sadašnjost, Provincijalat franjevaca trećoredaca.

RUNJE, Petar. 2012. Prema izvorima II. ur. Tomislav Galović. Krk-Zagreb: Povijesno društvo otoka Krka, Provincijalat franjevaca trećoredaca glagoljaša.

RUNJE, Petar. 2015. Fra Šimun Klimantović u svom vremenu. Ogulin: Ogranak Matice hrvatske Ogulin.

SKOK, Petar. 1971-1974. Etimologijski rječnik hrvatskoga ili srpskoga jezika I-IV. Zagreb: Jugoslavenska akademija znanosti i umjetnosti.

SLOVNÍK = Slovník jazyka staroslověnského, Lexicon linguae paleoslovenicae I-IV. 1958-1997. Praha: Academia, nakladatelství Československé akademie věd.

SRDOČ-KONESTRA, Ines, Saša LAJŠIĆ. 2008. Fra Šimun Klimantović (...) ni pisac ni pod piscem pisac. Fluminensia 20/1: 75-95.

STROHAL, Rudolf. 1915. Hrvatska glagolska knjiga. Zagreb: Vlastita naklada.

ŠIMIĆ, Marinka. 2000. Jezik Muke po Mateju u hrvatskoglagoljskim misalima. Slovo 50: 5-117.

ŠIMIĆ, Marinka. 2007. Kajkavizmi u Tkonskom zborniku. Rasprave Instituta za hrvatski jezik i jezikoslovlje 33: 343-370.

ŠIMIĆ, Marinka. 2008. Leksik psaltira Akademijina brevijara (III c 12). Slovo 56-57: 531-544.

ŠIMIĆ, Marinka. 2014. Akademijin brevijar. Zagreb: Staroslavenski institut.

ŠIMUNKOVIĆ, Ljerka. 2009. Hrvatsko-talijanski jezični dodiri u Dalmaciji. Split: Dante Alighieri.

TANDARIĆ, Josip Leonard. 1980. Hrvatskoglagoljski ritual. Slovo 30: 17-87.

TANDARIĆ, Josip Leonard. 1983. Crkvenoslavenska jezična norma u hrvatskoglagoljskom ritualu. Slovo 32-33: 53-83.

TANDARIĆ, Josip Leonard. 1993. Hrvatsko-glagoljska liturgijska književnost. Zagreb: Kršćanska sadašnjost, Provincijalat franjevaca trećoredaca.

ZELIĆ-BUČAN, Benedikta. 1972. Narodni naziv hrvatskog jezika tijekom hrvatske povijesti. Jezik 1, 1-18.

ZGUSTA, Ladislav. 1991. Priručnik leksikografije. Sarajevo: Svjetlost. 


\section{On Some Phonological and Lexical Features of Friar Šimun Klimantović's Croatian Glagolitic Miscellany of 1512}

Croatian Middle Ages with its Croatian Glagolitic written legacy represents an inexhaustible source in the study of language on this territory, both diachronic and synchronic. From the very beginning, Croatian Franciscan Tertiaries were using Glagolitza and Church Slavonic Language in their church service, and bore the honourable name glagoljaši ever since. Friar Šimun Klimantović was a Franciscan Tertiary, a scribe with a status of writer. He is known as one of the three most important individuals of the Glagolitic Humanism and was the first author of three books of rites. The most extensive in terms of content and compilation of ritual texts with different rituals is Klimantović's Croatian Glagolitic Miscellany (RitKlim) dating from 1512, which is kept in the archives of the Franciscan Tertiaries' Monastery of St. Francis Xavier in Zagreb.

The graphic features reflect the situation in the later Croatian Glagolitic texts. The letter $\boldsymbol{B}^{\mathrm{B}}$ occurs mostly as a number $(=8)$, as does the letter $\mathbf{\Psi}(=700)$. Among the less frequent letters recorded in the Croatian Glagolitic texts we find the letter $\boldsymbol{W}$ as a number $(=2000)$ and a letter $\mathbf{I}$, a sign for a semivowel $(I)$ as a number $(=3000)$. Among the ligatures we find a flattened version of the letter $m$, the so-called "fortress". The letter 罗 (î) is recorded in phonetic role only once in the word $\hat{\imath} \widetilde{z}$ avi. Words are shortened by a titla $(\mathcal{\sim})$ and we can find all known ways of shortening. Often there are ligatures, and among punctuation characters the most common is dot.

In the manuscript there are two characters for jer: štapić (I) can be found in few instances in both positions, in the middle of words (sbt'vori, prišasbtie, m $\widetilde{l s} r$ diem') and at the end of words (ubogimb, imb). The apostrophe (') prevails in both positions (dos 'toit', uz'mak'net', od'). Rejuvenation is evident from the examples with no characters for jer (naplni, nikim, zadržal'), where it is the case of a visible fallout of the strong semivowel, and there is often inconsistent placing of semivowels (jer) between two nearby consonants within a word (s'labos'ti, h'raniti). There is evident Čakavian jaka vokalnost with the preposition $v b$ and the prefix $v_{b}$ - (v'večer', v'vrat, vazmi), and there are only a few examples of transition $v b>u\left(u\right.$ koga, $\left.u s^{\prime} v i t\right)$. In the same position a semivowel is sometimes vocalized at the preposition odb < otb (oda v'sihb), as well as in internal syllables (vapiti, vas'pet'). In RitKlim we can find the Ikavian-Ekavian reflex of jat (nigovala, mes 'to) under the Meyer-Jakubinskij rule, as well as deviations from this rule (prominimo, zapovid', več'no). Nasal vowel $e$ after $j, \check{c}, \check{z}$ is mainly reflecting as a vocal $a$, which is typical for Čakavian dialect (êzika, čas 'to, žedaet', žainoga). The letter $\Phi$ occurs often, in foreign words (fuštanomb, oficii, an 'tifonb), but it is also replaced by the letter p (paraona, parêsa). The Čakavian feature is 
also represented by the remnant of the old consonant cluster $\check{c} r$ ( $\check{r} r n a, \check{c r} r$ 'eva). In choosing lexemes from spoken Čakavian language instead of Church Slavonic there is a direct influence of Friar Šimun Klimantović's spoken idiom. This is additionally confirmed by later loanwords (adurb, bula, guster'na, ban'dižati, baša, des'pot), particularly Croatisms where we differentiate Čakavisms (diti, leki, draže) and Kajkavisms (kaš'tig, tanacb, hiža), which also connect RitKlim with the northwest Čakavian dialect.

Keywords: Croatian Church Slavonic language, Glagolitic miscellanies, Friar Šimun Klimantović, phonology, lexis.

Ključne riječi: hrvatski crkvenoslavenski jezik, hrvatskoglagoljski zbornici, fra Šimun Klimantović, fonologija, leksik.

Katarina Lozić Knezović Filozofski fakultet Sveučilišta u Splitu HR-21000 Split, Sinjska 2 klozic@ffst.hr 


\section{FILOZOFSKI FAKULTET SVEUČILIŠTA U ZAGREBU \\ ZAVOD ZA HRVATSKU POVIJEST \\ INSTITUTE OF CROATIAN HISTORY \\ INSTITUT FÜR KROATISCHE GESCHICHTE}

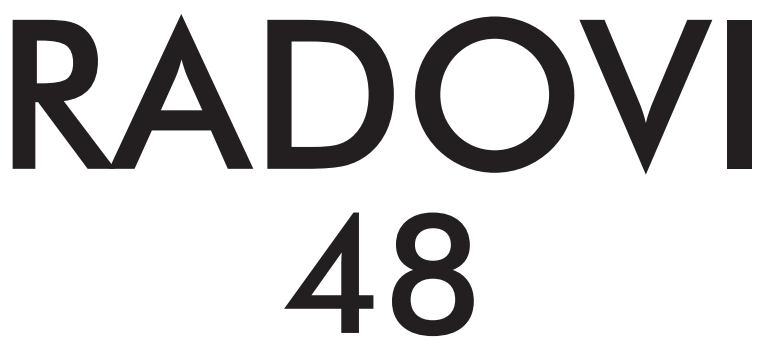

ZAVOD ZA HRVATSKU POVIJEST

FILOZOFSKOGA FAKULTETA SVEUČILIŠTA U ZAGREBU

\section{FF press}

ZAGREB 2016. 


\title{
RADOVI ZAVODA ZA HRVATSKU POVIJEST FILOZOFSKOGA FAKULTETA SVEUČILIŠTA U ZAGREBU \\ Knjiga 48
}

\author{
Izdavač / Publisher \\ Zavod za hrvatsku povijest \\ Filozofskoga fakulteta Sveučilišta u Zagrebu \\ FF-press \\ Za izdavača / For Publisher \\ Željko Holjevac \\ Glavni urednik / Editor-in-Chief \\ Hrvoje Gračanin \\ Izvršna urednica / Executive Editor \\ Inga Vilogorac Brčić \\ Uredništvo / Editorial Board
}

Bruna Kuntić-Makvić (stara povijest/ancient history), Zrinka Nikolić Jakus (srednji vijek/ medieval history), Hrvoje Petrić (rani novi vijek/early modern history), Željko Holjevac (moderna povijest/modern history), Tvrtko Jakovina (suvremena povijest/contemporary history),

Silvija Pisk (mikrohistorija i zavičajna povijest/microhistory and local history),

Zrinka Blažević (teorija i metodologija povijesti/theory and methodology of history)

Međunarodno uredničko vijeće / International Editorial Council

Denis Alimov (Sankt Peterburg), Živko Andrijašević (Nikšić), Csaba Békés (Budapest), Rajko Bratož (Ljubljana), Snježana Buzov (Columbus, Ohio), Svetlozar Eldarov (Sofija), Toni Filiposki (Skopje), Aleksandar Fotić (Beograd), Vladan Gavrilović (Novi Sad), Alojz Ivanišević (Wien),

Egidio Ivetić (Padova), Husnija Kamberović (Sarajevo), Karl Kaser (Graz),

Irina Ognyanova (Sofija), Géza Pálffy (Budapest), Ioan-Aurel Pop (Cluj),

Nade Proeva (Skopje), Alexios Savvides (Kalamata), Vlada Stanković (Beograd), Ludwig Steindorff (Kiel), Peter Štih (Ljubljana)

\section{Izvršna urednica za tuzemnu i inozemnu razmjenu / Executive Editor for Publications Exchange \\ Kristina Milković}

Tajnik uredništva / Editorial Board Assistant
Dejan Zadro

Adresa uredništva/Editorial Board address

Zavod za hrvatsku povijest, Filozofski fakultet Zagreb, Ivana Lučića 3, HR-10 000, Zagreb

Tel. ++385 (0)1 6120 150, 6120 158, faks ++385 (0)1 6156879

Časopis izlazi jedanput godišnje / The Journal is published once a year

Časopis je u digitalnom obliku dostupan na / The Journal in digital form is accessible at Portal znanstvenih časopisa Republike Hrvatske „Hrčak“ http://hrcak.srce.hr/radovi-zhp

Financijska potpora za tisak časopisa / The Journal is published with the support by

Ministarstvo znanosti, obrazovanja i športa Republike Hrvatske

Časopis je indeksiran u sljedećim bazama / The Journal is indexed in the following databases:

Directory of Open Access Journals, EBSCO, SCOPUS, ERIH PLUS, Emerging Sources Citation Index - Web of Science 


\section{Naslovna stranica}

Iva Mandić

Grafičko oblikovanje i računalni slog

Marko Maraković

\section{Lektura}

Samanta Paronić (hrvatski / Croatian)

Dražen Nemet (engleski / English)

Tisak

Tiskara Zelina d.d., Sveti Ivan Zelina

Naklada

250 primjeraka

Časopis je u digitalnom obliku dostupan na Portalu znanstvenih časopisa Republike Hrvatske ,Hrčak" http://hrcak.srce.hr/radovi-zhp

The Journal is accessible in digital form at the Hrcak - Portal of scientific journals of Croatia http://hrcak.srce.hr/radovi-zhp 


\section{RADOVI 48}

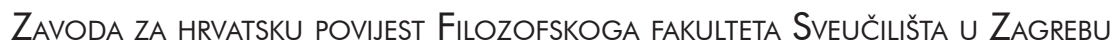

